\title{
The influences of forest stand management on biotic and abiotic risks of damage
}

\author{
Hervé JACTEL ${ }^{1 *}$, Bruce C. NICOLL ${ }^{2}$, Manuela BRANCO ${ }^{3}$, José Ramon GonZALEZ-OlABARRIA ${ }^{4,5}$, \\ Wojciech GRODZKI ${ }^{6}$, Bo LÅNGSTRÖM ${ }^{7}$, Francisco MOREIRA ${ }^{8}$, Sigrid NETHERER ${ }^{9}$, \\ Christophe Orazio ${ }^{1,10,11}$, Dominique PIou ${ }^{12}$, Helena SANTOS ${ }^{3}$, Mart Jan SchelhaAs ${ }^{13}$, \\ Karl ToJIC ${ }^{14}$, Floor VodDE ${ }^{1}$

\footnotetext{
${ }^{1}$ INRA, UMR 1202, Biodiversity, Genes and Communities, Laboratory of Forest Entomology and Biodiversity, 33610 Cestas, France

${ }^{2}$ Forest Research, Northern Research Station, Roslin, Midlothian, Scotland, UK EH25 9SY, UK

${ }^{4}$ Centre Tecnològic Forestal de Catalunya; Pujada del Seminari s/n, 25280 Solsona, Lleida, Spain

${ }^{5}$ Mediterranean Regional Office - EFIMED, European Forest Institute, Spain

${ }^{6}$ Forest Research Institute, Department of Forest Management in Mountain Regions, ul. Fredry 39, 30-605 Kraków, Poland

${ }^{7}$ The Swedish University of Agricultural Sciences, Department of Ecology, P.O. Box 7044, 75007 Uppsala, Sweden

${ }^{8}$ Centro de Ecologia Aplicada "Prof. Baeta Neves", Instituto Superior de Agronomia, Universidade Técnica de Lisboa, Tapada da Ajuda, 1349-017 Lisboa, Portugal

${ }^{9}$ University of Natural Resources and Applied Life Sciences, Department of Forest and Soil Sciences, Institute of Forest Entomology, Forest Pathology, and Forest Protection, Hasenauerstrasse 38, 1190 Vienna, Austria

${ }^{10}$ FCBA, Domaine de Sivaillan Les Lamberts 33480 Moulis en Médoc, France

${ }^{11}$ IEFC, 69, route d'Arcachon, 33612 Cestas, France

${ }^{12}$ Département de la Santé des Forêts, Ministère de l'Agriculture et de la Pêche, Impasse R. Lavigne 33150 Cenon France

${ }^{13}$ Centre for Ecosystem Studies, Alterra, Wageningen UR, P.O. Box 47, 6700 AA Wageningen, The Netherlands

${ }^{14}$ Albert-Ludwigs-University Freiburg, Institute for Forest Growth, Tennenbacher Str. 4, 79106 Freiburg, Germany
} \\ ${ }^{3}$ Centro de Estudos Florestais, Instituto Superior Agronomia, Universidade Técnica de Lisboa. Tapada da Ajuda, 1349-017 Lisboa, Portugal
}

(Received 1 December 2008; accepted 4 April 2009)

\section{Keywords: \\ silviculture / \\ stand / \\ occurrence / \\ susceptibility / \\ pest / \\ pathogen / \\ wind / \\ fire}

\begin{abstract}
- This article synthesizes and reviews the available information on the effects of forestry practices on the occurrence of biotic and abiotic hazards, as well as on stand susceptibility to these damaging agents, concentrating on mammal herbivores, pest insects, pathogenic fungi, wind and fire.

- The management operations examined are site selection, site preparation, stand composition, regeneration method, cleaning and weed control, thinning and pruning, and harvesting. For each of these operations we have examined how they influence the occurrence of biotic and abiotic damaging agents, the susceptibility of European forests, and describe the ecological processes that may explain these influences.

- Overall, we find that the silvicultural operations that have the largest influence on both biotic and abiotic risks to European forest stands are closely related to species composition and the structure of the overstorey. Four main processes that drive the causal relationships between stand management and susceptibility have been identified: effect on local microclimate, provision of fuel and resources to biotic and abiotic hazards, enhancement of biological control by natural enemies and changes in individual tree physiology and development.

- The review demonstrates an opportunity to develop silvicultural methods that achieve forest management objectives at the same time as minimising biotic and abiotic risks.
\end{abstract}

Résumé - Influences de la sylviculture sur le risque de dégâts biotiques et abiotiques dans les peuplements forestiers.

- Cette revue bibliographique s'intéresse aux effets de la sylviculture sur la sensibilité des peuplements forestiers aux principaux agents de dégâts biotiques et abiotiques que sont les mammifères herbivores, les insectes ravageurs, les champignons pathogènes, le feu et les vents forts.

\footnotetext{
*Corresponding author: herve.jactel@ pierroton.inra.fr
} 
herbivores / pathogènes / vent /

feu
- Les pratiques forestières analysées sont la sélection et la préparation des sites de reboisement, la définition de la composition en essences et le choix du matériel génétique, les méthodes de régénération et d'entretien, les modalités d'éclaircie et d'élagage, le mode de récolte finale. L'influence de chacune de ces opérations sur l'occurrence des agents de dégâts biotiques et abiotiques et sur la sensibilité des peuplements est examinée ainsi que les processus écologiques sous-jacents.

- Les opérations sylvicoles qui se révèlent les plus déterminantes pour la sensibilité des forêts en Europe sont celles qui affectent la composition et la structure de la strate arborée. Quatre principaux processus écologiques semblent expliquer la relation entre sylviculture et sensibilité des peuplements : la modification du micro-climat, l'apport de ressources ou de combustible aux agents de dégâts, l'amélioration du contrôle biologique par les ennemis naturels et l'altération de la physiologie et du développement des arbres.

- Cette revue permet donc d'envisager le développement de méthodes de gestion des peuplements forestiers qui permettent d'atteindre les objectifs de production tout en minimisant les risques de dégâts sanitaires.

\section{INTRODUCTION}

European forests are among the most intensively managed forests in the world and only $0.4 \%$ of the European forest area is covered by non-managed protected forests (MCPFE, 2002). Forest ecosystems are a vital source of wood and non-wood products and provide numerous services such as nature conservation, protection of soil and water, recreation, and carbon storage. The forest area is currently increasing by about 760000 ha $(0.4 \%)$ per year in Europe, the average growing stock increased from $124 \mathrm{~m}^{3} \mathrm{ha}^{-1}$ in 1990 to $141 \mathrm{~m}^{3} \mathrm{ha}^{-1}$ in 2005 (FAO, 2007), and this trend is projected to continue for the next few decades. However other trends give reason for concern, particularly the increase in natural disturbances to forests. Natural disturbances are defined here as any hazard such as fire, windstorms, ice, flood, pest or pathogen outbreaks, that disrupt ecosystem structure or function for time periods longer than the current seasonal vegetation cycle. The annual disturbed forest area in Europe is around 10 million ha (6\% of the total forest area) (FAO, 2007) with the disturbed volume being about $8.1 \%$ of the annual harvest (Schelhaas et al., 2003). Many types of disturbance have increased over recent decades (Schelhaas et al., 2003), mainly in relation to changes in forest resource characteristics such as forest area, growing stock and the proportion of conifers, but possibly also as a result of climate change.

Thus, evaluating the risk of damage is crucial for forest planning. Risks can theoretically be described as the interaction between hazard likelihood, susceptibility and exposure (Kron, 2002). Any change in one of these factors will lead to a corresponding change in risk level. Hazard likelihood is the probability of occurrence, which is related to external factors such as the climate or internal drivers like pest population dynamics. Susceptibility relates to how easily the system, e.g. the forest, is damaged by the disturbance agent under consideration. Exposure can be understood as the values that are at stake, i.e. to what extent forest functions will be impacted (Fig. 1).

Forest management may have an effect on all three components of the risk of damage. Silvicultural practices are in principle designed to optimize one or several forest functions, e.g. wood production, soil protection, and biodiversity conservation, and therefore they influence the forest exposure to hazards. Forest functions are often determined according to socio-economic constraints and managers are unlikely to limit the forest value just to reduce exposure to hazards. In contrast, once forest objectives have been settled, forest managers may want to make compromises in management decisions in order to minimize both hazard likelihood and stand susceptibility to hazards. However they often do not have the information they need to take these components of the risk into account. For example, a recent study by Blennow and Sallnäs (2002) revealed that in Southern Sweden although forest owners rank storm damage highly as a potential risk, most do not know how to change their forest management to reduce it. The choice of tree species, the preparation of the site, and thinning or harvesting operations, will all have profound effects on the composition and structure of forest stands, and as a consequence, on the occurrence of damaging agents and on stand susceptibility (for example, see Wainhouse (2005) for forest pests, Tainter and Baker (1996) for pathogens, Quine et al. (1995) for wind, Peterson et al. (2005) for fire). However, there is a wide variety of potential disturbance agents, and each may have a specific response to stand management decisions. In order to decrease the risk of future disturbances having large detrimental impacts on forest function, we need a clearer understanding of how management decisions influence both the likelihood of a range of different agents and the forest susceptibility to such hazards.

The objective of this review is to synthesize available information on the effects of management options on both the likelihood of, and susceptibility to, different disturbance agents at the forest stand level. Agents considered here are the most common biotic and abiotic hazards in Europe: mammal herbivores, pest insects, pathogenic fungi, wind and fire. Although we focus on European conditions, literature from outside Europe has been included where it is relevant. We have divided management operations into seven categories according to a sequential order: site selection, site preparation, stand composition (including tree genetic material), regeneration method, cleaning and weed control, thinning and pruning, and harvesting (Jactel et al., 2008). For each of these operations, we review how they influence the occurrence of damaging agents and the susceptibility of forest stands. We then propose ecological explanations for the observed patterns. 


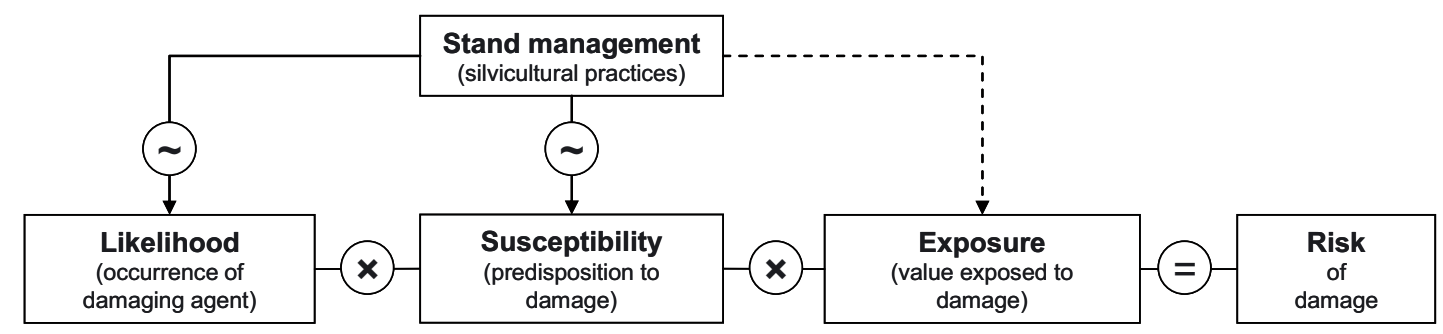

Figure 1. Diagram illustrating the influence of stand management on the three components of risk. Solid and dash arrows indicate that this review focuses on hazard likelihood and forest susceptibility since exposure mainly depends on socio-economic issues.

\section{SITE SELECTION}

Site selection in the truest sense of the word is rarely a real option, because the available forest land is usually limited in terms of area and location. The process of selection mostly happens the other way round, in that forest managers will adapt their choice of silvicultural measures to given site characteristics. Matching given site conditions to the demands of the target tree species may be suitable options for minimising forest susceptibility to damage. Hence, the causalities discussed in the following are of importance not only at the time of forest establishment, but for all subsequent management decisions until harvesting.

When comparing the occurrence of forest disturbance with respect to site related parameters, some trends become evident. There are specific microclimatic conditions which influence even very different factors in a similar way and predispose forests to damage. A striking example is the effect of temperature. Thermal conditions play a crucial role in the success of all organisms, influencing growth, population dynamics, and survival. Relatively warm, protected sites serve as habitats for a variety of species, being preferred to sites exposed to harsher climates. A multitude of insect species find optimum conditions for reproduction and development in thermally favoured areas and will benefit from periods of high temperature and/or precipitation deficits. As at the same time the vitality of forests may be impaired, such climatic conditions frequently trigger mass propagation of insect pests, e.g. of the European spruce bark beetle, Ips typographus (Baier et al., 2007; Netherer and Nopp-Mayr, 2005; Wermelinger, 2004), the web-spinning sawfly, Cephalcia arvensis (Marchisio et al., 1994) in stands of Norway spruce, or the gypsy moth, Lymantria dispar in deciduous forests (Hlasny and Turèaní, 2008). Most pathogenic fungi of the temperate forests need temperatures between 20 and $30^{\circ} \mathrm{C}$ for optimal mycelium growth (Tainter and Baker, 1996). Rising temperatures, e.g. under a climate change scenario, will favour the development of forest pathogens that have been introduced from Mediterranean or tropical countries, such as Sphaeoropsis sapinea, Phytophthora spp. and Biscognauxia mediterranea (Desprez-Loustau et al., 2006). In the case of fire, higher temperatures correspond to higher stand susceptibility (Rothermel and Philpot, 1973). On the other hand there are several pathogen and pest species that show a preference for lower temperatures and therefore prefer sites of higher altitude and latitude, such as
Scleroderris canker on lodgepole pine (Pinus contorta) in Sweden (Karlman et al., 1994), or the larch budmoth, Zeiraphera diniana in the Alps (Baltensweiler and Fischlin, 1988) and Sudeten (Capecki et al., 1989).

Temperature alone does not sufficiently explain site susceptibility to disturbances and cannot be considered detached from other climatic conditions. Sites offering favourable conditions for spore infection, such as high humidity or low air movement, are to a greater extent susceptible to fungal diseases. For example, the most severe damage caused by the pine shoot blight and canker, Sphaeropsis sapinea, are found in protected valley sites (Wingfield and Swart, 1994), while spruce stands on slopes or hilltops with a high incidence of fog and westerly winds of high humidity are highly disposed to shoot blight, Sirococcus conigenus (Anglberger and Halmschlager, 2003). In contrast, stands with lower moisture are more susceptible to fire hazard (e.g. Gonzalez and Pukkala, 2007; Mermoz et al., 2005; Mouillot et al., 2003). Soil moisture deficits resulting in moisture stress of host plants can in many cases be correlated with elevated insect or fungal damage (Caldeira, 2002; Desprez-Loustau et al., 2006; Major, 1990; Selander and Immonen, 1991; Stone, 2001; Worrell, 1983). Soil humidity plays an important role in the mortality of insects pupating in the upper soil or humus layers, such as certain species of defoliators, e.g. the little spruce sawfly, Pristiphora abietina (Netherer and Führer, 1999), the false spruce webworm, Cephalcia abietis (Führer and Nopp, 2001) and the pine processionary moth Thaumetopeoa pityocampa (Markalas, 1989). Soil water supply or soil temperature conditions are also crucial in the question whether forests have to cope with harmless saprophytic organisms or with pathogens. Depending on the species, e.g. Armillaria spp., Collybia fusipes, Heterobasidion annosum, Phytophtora cinnamoni, pathogenicity may either be reduced or enhanced with drought and increased stress of the host trees (Camy et al., 2003; Desprez-Lousteau et al., 2006; Wargo and Harrington, 1991; Woodward et al., 1998).

Microclimatic conditions are modified by site related features such as elevation, aspect and topography. Slopes exposed to high rates of solar irradiation or stands on upper slopes, ridges or hilltops are particularly prone to storm damage (Führer and Nopp, 2001; Ni Dhubhain et al., 2001; Winterhoff et al., 1995). The probability of storm damage on slopes of certain gradients and exposure depends on the wind direction prevailing in a specific area (Ni Dhubhain et al., 2001; 
Schreiner et al., 1996; Werner and Armann, 1955). In the case of fire, altitudinal patterns in stand susceptibility are the result of variations in moisture and temperature, but also in human ignitions, as altitude is usually negatively correlated with population density. A slope affects the speed of fire spread, and its intensity, by increasing the radiant energy transfer from flaming fronts to upslope fuels (Agee, 1993; Pyne et al., 1996; Rothermel and Philpot, 1983).

Forest health is strongly dependant on soil conditions and the adaptation of plants to given states of soil structure, acidity or nutrient availability. Adverse conditions in the rhizosphere leading to lesions of the root system render forest stands especially susceptible to fungal diseases and windthrow. Any factor that decreases rooting depth, such as frequent waterlogging (Laiho, 1987; Offergeld, 1986; Poeppel, 1994; Schreiner et al., 1996; Van Nispen tot Sevenaer, 1975) or soil compaction (Andersen, 1954) can negatively affect anchorage (Nicoll et al., 2006). The effect of such adverse conditions on stand stability varies with the tree species, as well as the rooting system's ability of adaptation (Nicoll and Ray, 1996; Xu et al., 1997). Forest stability is also affected by the previous land use of a site, as conifer stands on former arable land are especially susceptible to Heterobasidion root rot (van Soest, 1954). Many studies of fungal diseases point to a positive relationship between soil fertility and the susceptibility to infection (e.g. Blodgett et al., 2005; Woodward et al., 1998). There is considerable evidence that the enhanced availability of nitrogen is also a key factor in the improved nutritional quality of host tree foliage to various, but not all, forest pests (Kytö et al., 1996a, 1996b; Pinkard et al., 2006). Therefore, forest sites affected by nitrogen input, either originating from fertilised, adjacent agricultural land or from atmospheric deposition of pollutants, may be especially prone to herbivory.

\section{SITE PREPARATION}

Site preparation techniques to improve the conditions for afforestation or regeneration and growth are common in intensive forestry, and include water management, such as drainage and irrigation, and soil cultivation, such as ploughing, harrowing, scarification or mounding. These silvicultural treatments, as well as decisions concerning brash and stump management, weed control, prescribed burning, fertilisation, and the use of fallow periods may affect the susceptibility to forest biotic and abiotic agents in either positive or negative ways, depending on the type of application and the hazard.

Positive effects on forest health of stump, brash or understorey removal during site preparation may result from a reduction in the amount of resources for biotic and abiotic damaging agents. In particular, stumps represent the breeding substrate of Hylobius abietis (Speight and Wainhouse, 1989), Armillaria (Legrand et al., 2005) and Heterobasidion annosum (Gibbs et al., 2002; Korhonen et al., 1998), which are among the most severe pests and pathogens in European conifer forests, and removal of the substrate should decrease the risk of infection to neighbouring living trees. The use of a fallow period between final harvesting and reforestation is one method to reduce the quality of the breeding substrate, taking advantage of progressive decomposition of the stumps (Gibbs et al., 2002; von Sydow, 1997). Similarly some bark beetles, e.g. Ips pini (Gara et al., 1999; Six et al., 2002), Hylastes angustatus (Wingfield and Swart, 1994) or Pityogenes chalcographus (Grodzki, 1997) find breeding resources in woody debris, and slash management prevents them from building up their population to the high levels that would lead them to attack living trees. Small rodents can use brash and then cause significant damage on newly planted seedlings (Wingfield and Swart, 1994). Brash removal and prescribed burning will also significantly decrease susceptibility to fire hazard, as fuel load is a key aspect influencing fire ignition, spread and intensity (Rothermel and Philpot, 1983). Mechanical (scarification) or chemical applications to remove understorey vegetation have been shown to reduce browsing by roe and red dear (Huss and Olberg-Kalfas, 1982; Roth and Newton, 1996) as well as by voles (Clethrionomys spp. and Microtus spp.) and to decrease damage by the pine weevil Hylobius abietis (Örlander and Nordlander, 2003; Petersson et al., 2006; Pitkanen et al., 2005). Site preparation operations which provide even resources around trees for symmetrical development of tree roots may increase stand resistance to strong winds (Coutts et al., 1999), just as drainage and tilling can increase the effective rooting depth (Ni Dhubhain et al., 2001; Ray and Nicoll, 1998). In contrast prescribed burning may improve conditions for some root diseases such as Rhizina inflata (Savill et al., 1997) and R. undulata (Germishuizen, 1984), and ploughing may favour $H$. annosum (Redfern, 1984) and Armillaria ostoyae (Lung et al., 1997) via the dissemination of rhizomorphs.

The effects of fertilisation on forest health is somehow more difficult to interpret as experiments have shown both positive and negative effects, sometimes on the same pest, or where the use of alternative fertilisers, such as $\mathrm{N}$ or $\mathrm{P}$, may lead to opposite effects. However beside these apparent contradictions, causal relationships between fertilisation and tree resistance have been demonstrated (e.g. Kytö et al., 1996a,b; Wainhouse, 2005). Fertilisation can improve the quality of food for some mammal herbivores, insect pests and pathogenic fungi. For example, the use of nitrogen fertilisers results in increased leaf $\mathrm{N}$ content which benefits leaf chewers, including voles (Microtus agrestis, Rousi et al., 1993), hares (Lepus timidus, Mattson et al., 2004), some sawflies (Gilpinia hercyniae, Wainhouse et al., 1998), moths (Rhyacionia frustrana, Sun et al., 2000), and aphids (Adelges piceae, Carrow and Betts, 1973; Elatobium abietinum, Wainhouse et al., 1998). Similarly, nitrogen fertilisation has been shown to promote infection by Mycosphaerella pini, Mycosphaerella quercina, Cryptodiaporthe populea and Melampsora pinitorqua (Lopez-Upton et al., 2000) and phosphorus fertilisation can induce changes in the nutritional status of pines, making them more susceptible to damage by twisting rust Melampsora pinitorqua (Desprez-Loustau and Wagner, 1997b). Fertilization can also favour tree growth which in turn benefits primary pests and pathogens, such as Dioryctria sylvestrella (Jactel et al., 1996) and Hylobius abietis (Zas et al., 2006). When fertilization results in faster understorey growth, it may increase 
fire risk. The nitrogen fertilization which favours the development of branches and leaves may also reduce the bending resistance of trees (Mitchell, 2003). In contrast fertilization of nutrient-limited plants is predicted to increase the synthesis of secondary chemicals like terpenic and phenolic compounds that are toxic for many pest insects and fungal pathogens (Herms, 2002) which would explain the negative effects of fertilization on some pests and pathogens. For example, insect defoliators such as the pine sawflies Neodiprion swanei and Neodiprion sertifer (Larsson and Tenow, 1984; Smirnoff and Bernier, 1973), or the poplar chrysomelids Chrysomela tremulae and Phratora vitellinae (Gruppe et al., 1999) are adversely affected by nitrogen fertilization of trees. Similarly, it has been observed that the number and size of resin ducts increases in fertilised conifers (Kytö, 1999; Wainhouse et al., 2005). Because resin compounds are toxic for bark feeders such as bark beetle and weevils (Wainhouse et al., 2005) or repellent for mammal herbivores such as voles and hares (Harju and Tahvanainen, 1997), it follows that fertilised trees would be less damaged by these agents.

\section{STAND COMPOSITION}

The primary decision to make before afforesting or reforesting is to select the tree species. This will obviously depend on both site conditions and on market or public demand for forest products or services, but once the decision is made it will influence most of the silvicultural practices to be implemented. Forest managers must then decide if the selected species will be grown alone or in association with others.

At the forest level the maintenance of tree diversity has the advantage of spreading risk. Because different species will not be equally susceptible to particular biotic or abiotic hazards, the more tree species in a stand, the more likely it is that the stand contains trees that will escape infection, infestation, windthrow, or fire damage. These surviving trees may then fill the gaps, maintaining the structure and the functioning of the forest. A major argument for mixed stand forestry is therefore the "insurance hypothesis" (Loreau et al., 2001; Pautasso et al., 2005), which states that diverse ecosystems will respond in a more buffered way to disturbance (higher resistance) and recover more quickly (higher resilience) than monocultures. This is well illustrated by forest stand susceptibility to wind and fire. Different species present different characteristics in terms of morphology, shade tolerance, moisture content, and chemical composition that influence the availability and combustibility of the forest fuels (Dimitrakopoulus and Papaioannou, 2001; Wang, 2002). For example, coniferous species are highly flammable due to the high content of resins and essential oils (Bond and Van Wilgen, 1996; Dimitrakopoulus and Papaioannou, 2001; Velez, 1990), increasing not only the probability of fire occurrence in pine dominated forest (González et al., 2006; Moreira et al., 2001) but also the potential damage caused by fire in terms of severity and tree mortality (González et al., 2007b; Wang, 2002). Thus, the fire hazard in pure conifer stands is usually higher than in deciduous hardwoods, whereas mixed conifer- deciduous stands have intermediate fire hazard (González et al., 2006; Moreira et al., 2001). Likewise, some tree species are more susceptible to windthrow than others (Colin et al., 2008; Wolf et al., 2004). In general, broadleaves are regarded as being more stable than conifers (Bryndum, 1986; Holmsgaard, 1986), probably because broadleaves are usually leafless in winter, the period where most storms occur. Several authors report a higher stability of mixed species stands as compared to monocultures (Grodzki et al., 1999; Lekes and Dandul, 2000; Schütz et al., 2006; Slodicak, 1995) but others argue that damage to a mixed species stand will only be reduced equal to the share of the stable species (Lüpke and Spellmann, 1997). Dhôte (2005) also concluded that tree species identity is more important in predicting wind damage to mixed stands than species richness.

When considering a particular tree species, two main ecological constraints should be taken into account in the decision of whether growing it in a mixed stand would reduce the risk of biotic damage: i.e. the accessibility of host trees, and the impact of natural enemies (Jactel et al., 2005). The admixture of other species with a focus tree species is expected to reduce its accessibility, and then its use, by grazers, insect pests or fungal pathogens (Jactel et al., 2005). First, for a given stand, increasing the number of tree species will decrease the abundance of trees from the focus species. The lower concentration of food resources may in turn prevent pest and pathogens from developing and building up their populations thus reducing the risk of damage on focus trees (Jactel and Brockerhoff, 2007). Second, non-host trees may provide physical or chemical barriers to host location or colonization. Forest insects (e.g. Matsucoccus feytaudi, Jactel et al., 2006) and pathogens that are passively wind dispersed have a lower chance of landing on the appropriate host tree in mixed stands (Heybroek, 1982). Several tree diseases (such as H. annosum) spread through root contacts and the presence of non-host trees may limit this process (Linden and Vollbrecht, 2002). Some forest insects (Watt, 1992) and mammalian herbivores (Pietrzykowski et al., 2003) use visual cues to locate their host, and the presence of other tree species can effectively hide the host trees. Conifer-inhabiting bark beetles are able to perceive non-host volatiles released by angiosperm trees and to use them to avoid non-suitable habitats (Zhang and Schlyter, 2004). In mixed stands host tree saplings can also be protected against mammalian grazers by non-host, nurse plants in the form of physically (thorns) or chemically (toxins) defensive species (Smit et al., 2007). Third, damage by generalist insect or mammalian herbivores on a focus tree species may also be reduced in tree mixtures that contain other, more palatable, secondary tree species, which would be exploited first. Such a diversion process has been demonstrated in mixed eucalypt stands for Amblypelta cocophaga (Bigger, 1985) and Chrysophtharta bimaculata (Elek, 1997) by planting alternative, preferred shrub or tree species that concentrated pest attacks. However, polyphagous pests or generalist pathogens can cause more damage in mixed stands. This process is comparable to contagion and happens when a generalist herbivore first builds up its population on a more palatable tree species, exploits the main part of this resource, and then transfers to other 
host trees (White and Whitham, 2000). In their meta-analysis comparing insect herbivory in pure vs. mixed stands, Jactel and Brockerhoff (2007) found twenty-one studies where more palatable host trees were included in the mixture and these mixed stands were more damaged overall than pure stands. The presence of a preferred species (high quality food resource) in a mixed stand increased the level of damage on less preferred species (low-quality food) by mammalian herbivores such as vole and moose (Pusenius et al., 2003; Vehviläinen and Koricheva, 2006). The intensity of Armillaria damage increases with the number of susceptible conifer species in mixed plantations (Gerlach et al., 1997). Associating particular tree species may also increase mixed stand susceptibility to heteroecious fungal pathogens. These fungi require two alternative, unrelated hosts to complete their life cycle and if both of these host trees are present in the same mixture, the stand is more likely to experience severe damage. The best known example is the pine twisting rust caused by Melampsora pinitorqua which uses Scots pine and aspen (Populus tremula) as main hosts (Mattila, 2002; 2005). Recently, Phytophthora ramorum and $P$. kernoviae have been found infecting oak and beech in England with rhododendron and viburnum serving as reservoir hosts (Brasier et al., 2005).

The second main explanation of why mixed stands would be less prone to pest and pathogen damage than pure stands is the enhancement of control by natural enemies (Jactel et al., 2005; Root, 1973). Generalist predators and parasitoids would benefit from the range of alternative preys or hosts (Siemann et al., 1998). Tree mixtures are also more likely to accommodate plants providing a better supply of complementary food that help adult specialised parasitoids to prolong their lifespan. The longevity is significantly increased in parasitoids of Rhyacionia buoliana (Syme, 1975) or Ips typographus (Hougardy and Grégoire, 2000) when the wasps are exposed to nectariferous flowers commonly found in conifer stands. Because they are structurally more complex, mixed forests also offer more shelters from adverse conditions to natural enemies (Finke and Denno, 2002) and more nesting sites to insectivorous birds (Barbaro et al., 2007; Dickson, 1979). Finally, it has been suggested that mixtures of tree species would better accommodate antagonistic fungi that slow the spread of fungal pathogens such as H. annosum (Fedorov and Poleschuk, 1981; Johanson and Marklund, 2008) and Phytophthora cinnamomi (Murray, 1987).

Once a tree species has been chosen for afforestation, notably in pure stands, selecting adequate tree genetic material for a specific site is a key step in forest planning. Among other implications this selection process may prevent or limit forest damage by avoiding susceptible plant materials in high hazard areas to a given damage agent (e.g. Wingfield and Swart, 1994). To date, genetic selection has been focussed mostly towards an increase in tree productivity and an improvement in the quality of forest products (e.g. Dini-Papanastasi, 2008; MacDonald et al., 1997). However, forest susceptibility, in particular related to the risks to intensive forestry and the invasion of exotic pests and diseases, is a major concern and justifies attempts to breed for tree resistance (e.g. Heimburger, 1962; Robin and Desprez-Loustau, 1998; Toda et al., 1993).
Regarding abiotic agents, genetic variation was found on root architecture, anchorage and stem properties which could be related with resistance to windstorm (e.g. Nicoll et al. 1995; Silen et al., 1993; Stokes et al., 1997). Concerning fire, the survival capability of a tree to fire has been related to variables such as the tree size, bark thickness, tree architecture and vigour (Hély et al., 2003; Linder et al., 1998; Ryan and Reinhardt, 1988; Van Mantgem et al., 2003) which are at least partly under genetic control.

Tree susceptibility to pests or pathogens relies on two major mechanisms: tolerance, which reflects tree ability to compensate for damage by sustaining growth and reproduction levels; and resistance, which reflects the ability to escape herbivory, through phenological isolation, dissuading traits and limiting insect or pathogen performance (Restif and Koella, 2004). These mechanisms are partly genetically inherited and several studies have shown differences in susceptibility between host species and intra-specifically within clones or families (e.g. Barre et al., 2002; Pasquier-Barre et al., 2000; Zas et al., 2005). Thus, selecting tolerant/resistant families or clones may be an effective strategy in minimizing losses caused by pests and pathogens.

Although genetic variability has been extensively reported in relation to tree resistance to pests, pathogens and abiotic agents, breeding for resistance may raise several difficulties. Resistance is commonly highly specific, necessitating breeding programs directed to a particular agent. Further, heritability of resistant traits is frequently low $(<0.5)$ (Dungey et al., 1997; Kleinhentz et al., 1998), making the selection process difficult. Resistant traits may be negatively correlated with growth or wood quality traits, and therefore compromises may be needed (Kleinhentz et al., 1998). An alternative could be breeding hybrids associating productive and resistance traits (e.g. Harfouche and Kremer, 1995; Kraus, 1986). Yet, a tendency for F1 hybrid to be more susceptible than resistant parents may hinder its use (e.g. Dungey et al., 1997; Highsmith et al., 2001). Plants with high levels of induced resistance to a specific agent may also be susceptible to others. These shortcomings explain why very few tree breeding programs have included such traits (FAO, 2007). However, there are a few good examples, such as tree breeding programmes in Europe for elm resistance to Ophiostoma ulmi (Pinon and Cadic, 2007) and poplar resistance to foliar rust (Berthelot et al., 2005).

As for the tree species composition of forest stands, it has been suggested that planting genotypes mixtures that differ in susceptibility may reduce pest and disease incidence in comparison with monoculture of one genotype. Although few studies have tested this assumption, focussing mainly on poplars and willows, overall they have shown a reduction of damage in mixtures. Lower infestation of rust disease was reported in polyclonal plots compared with monoclonal plots in poplar (Melampsora epitea, McCracken and Dawson 1997; Melampsora larici-populina, Miot et al., 1999) as well as in genotypes mixtures of willow (Melampsora spp., Peacock et al., 2001). A reduction in the overall density and damage of leaf beetles (Phratora vulgatissima) was observed in mixtures of willow genotypes compared with monocultures (Peacock and Herrick 2000, Peacock et al., 2001). Proposed mechanisms to interpret 
these patterns are dilution of susceptible individuals and physical barriers provided by resistant plants (Miot et al., 1999).

Anticipating what will happen over time in a genetically improved resistant forest plantation is a pertinent concern. The insect or pathogen response to a given genetic material is not static but the outcome of a dynamic evolutionary process (Neuhauser et al., 2003). This is illustrated by the increase in susceptibility of transgenic materials resistant to insects after some generations (e.g. Frutos et al., 1999). Conservation of the genetic diversity of trees is therefore vital, for future use in adapting forests, not only towards new products or new silvicultural practices, but also as sources of possible genetic resistant materials for when climate change, new silvicultural techniques, or introduced pests or diseases increase forest susceptibility.

\section{REGENERATION METHODS}

The favoured tree species dictates, to a large extent, the chosen method of forest regeneration, along with site conditions and local forest practice. A wide range of forest regeneration methods have been applied throughout Europe, ranging from intensive to "close-to-nature" forestry. Replanting after clear-felling is still a common practice for regenerating a range of native and non-native forest tree species including Norway spruce, Sitka spruce, Scots pine, lodgepole pine, maritime pine, eucalyptus and genetically selected cultivars of, for example, poplar and birch. In many cases this results in uniform, even-aged stands. In less intensively managed forests, there is a trend towards the maintenance of continuous forest cover over time. Mature individuals are removed from the stand, creating small forest gaps that are filled by natural regeneration, finally ending with multi-layered stands that have a diversity of tree species and age classes. It is therefore the choice of regeneration method which mainly determines stand structure.

There is no clear reason why uneven-aged or multi-storied forest stands would differ in susceptibility to biotic hazards from even-aged or regular stands. On one hand uneven-aged pure stands may provide a more diverse diet to different pests and pathogens and therefore may suffer from a larger array of aggressors. On the other hand even-aged stands can represent a large, stable and predictable food resource that can benefit food density-dependant pests (e.g. Hylobius abietis, Lof et al., 2005; Nordlander et al., 2003; Pitkanen et al., 2005) and pathogens (e.g. Heterobasidion annosum, Korhonen et al., 1998). Barthod (1995), Landmann (1998) and Muzika and Liebhold (2000) indicate in their reviews that the effect of stand structure has never been adequately addressed and that too many confounding factors, such as stand composition, history of management and site conditions, probably obscure the issue. The same uncertainty remains for susceptibility to forest gales. Quine et al. (1995) argue that even and closely packed stands are better from an aerodynamic viewpoint to resist strong winds. Dhôte (2005) suggests that even-aged forests may be more resistant because of their lower canopy roughness, better dissipation of wind energy between swaying crowns of similar heights and lower crown-exposed area.
However, many authors expect greater stability of unevenaged systems due to overstorey trees becoming acclimated to the wind (Cameron, 2002; Mason, 2002). Selection forests would be more wind resistant mainly due to higher individual tree stability resulting from better shape (lever arm and bole taper) and better acclimation to wind (Dhôte, 2005). Stand structure is linked to fire hazard through its influence on fuel availability at the crown (live and dead material in the canopy of trees) and surface (shrubs, grass, litter, and woody debris in contact with the ground) levels. Modification of any of these fuel strata by silvicultural operations will thus have implications for fire behaviour, severity and suppression effectiveness (Peterson et al., 2005). Mature even-aged stands are usually more resistant to fire than multi-layered or young stands (Agee et al., 2000; Fernandes and Rigolot, 2007; González et al., 2007b; Omi and Martinson, 2004; Pollet and Omi, 2002), and have lower probability of being affected by fire (González et al., 2006). Thus, regeneration methods that drive the development of stands to even-aged structures (clear cuttings followed by planting or very intense shelterwood methods) are expected to reduce susceptibility to fire. On the other hand, these methods usually require intensive cuttings that can produce large amounts of slash. This accumulation of dead fuel can produce a temporal increase in the risk of fire if no additional treatment is considered to reduce it (Carey and Schumman, 2003). Additionally, during early stages of development, even-aged stands are characterized by abundant understorey vegetation due to canopy opening, which can lead to the accumulation of very flammable surface fuels (Gonzalez and Pukkala, 2007; Gonzalez et al., 2007a; Moreira et al., 2001; Pollet and Omi, 2002).

Nursery practices including irrigation, fertilisation, fungicide applications and short rotations are considered to be the main drivers for the persistence of asymptomatic pathogens in young seedlings. Fertilised seedlings may be also more appetent for insects (Hylobius abietis, Selander and Immonen, 1991; Zas et al., 2006) and mammal grazers (Rousi et al., 1993) and more susceptible to some pathogens. For example the higher susceptibility of planted, compared to sown, pine to the twisting rust $M$. pinitorqua may result from a larger amount of susceptible tissues in the elongating shoot (Desprez-Loustau and Wagner, 1997a; 1997b). On the other hand fertilised seedlings may better resist secondary pests and pathogens which prefer stressed trees (see above, site preparation). Nurseries are also the main gateways for the introduction of disease to forests, and therefore there is a higher risk of infection in plantations. The density of seedlings is relevant to predict the susceptibility of plantation forests. Low density plantings may favour pest insects that select more isolated seedlings, such as shoot moths like $R$. buoliana, or tree defoliators like T. pityocampa which are visually attracted by tree silhouettes against clear background (Demolin, 1969). High density plantings are more prone to disease that spread through root contacts such as H. annosum (Woodward et al., 1998) and Armillaria sp. (Morrison and Mallett, 1996). The succession of clear-cutting and regeneration through planting offers the best conditions for development of pests and pathogens, such as pine weevil H. abietis (Långström and Day, 2002) 
and the root rot $H$. annosum (Woodward et al., 1998), which first colonise stumps and then damage neighbouring seedlings. These two operations should therefore be separated in time or space to avoid severe damage to conifer plantations.

\section{CLEANING AND WEED CONTROL}

In intensively managed forests, cleaning and weed control are operations that are considered to improve tree growth by decreasing competition (e.g. Nowak et al., 2003; Ross et al., 2005). Depending on the techniques and the objectives, the understorey vegetation can be totally removed or some vegetation between lines can be left so that the impact on biodiversity is reduced. Commonly, the removal of understorey vegetation can be achieved through the use of mechanical operations, application of chemicals, or prescribed burning.

Understorey vegetation may reduce herbivory by limiting access to seedlings and diverting herbivores with other food sources, but, conversely, it may favour herbivores and pathogens by providing shelters and alternate hosts.. First, dense vegetation or heavy slash may impede mammal herbivore movement (Emmingham et al., 1989; Rochelle, 1992), and unmanaged understorey, especially with a high concentration of thorny species such as Rubus or Ulex, may simply be impenetrable, even for deer. The seedlings become more noticeable to foraging deer when the understorey vegetation is removed around them (Black, 1992; Brandeis et al., 2002; Guibert et al. 1992). Likewise pine tip moths (Rhyacionia sp.) probably locate host tree seedlings that stand out from the understorey layer so that high vegetation may better conceal young conifer seedlings (Ross et al., 1990; Sun et al., 1998, 2000). Second, the presence of other palatable species in the understorey may provide an alternative to planted seedlings as herbivores primarily forage on their preferred plant species, this is particularly true when broadleaved shrub species are present in the understorey of conifer plantations (Brandeis et al., 2002; Guibert et al., 1992; Örlander et al., 2001). However, when the preferred food resource becomes scarce, there is a risk of spill over of herbivores onto less preferred but still present host species such as tree seedlings. Yet, shrubs can also provide shelters for small mammal herbivores such as hares (Oxenham, 1983) and insect pests (e.g. Hylobius abietis Björklund et al., 2003) where they can hide and repeatedly return to feed on seedlings, thereby causing serious damage. For several pathogenic fungi such as Phytophthora, the understorey vegetation may also serve as a reservoir thus increasing the inoculum pressure on neighbouring trees or seedlings (Brasier et al., 2005; Maloney et al., 2005; O'Hanlon-Manners and Kotanen, 2004). Some heteroecious fungal pathogens, such as the rust disease Melampsora pinitorqua, need to alternate between two different host plants, one of which is often present in the understorey vegetation. The survival of the spores depends on the distance between individuals of these two hosts which obviously increases following weeding operations (Nageleisen et al., 2002). Similarly several bark beetle species can benefit from slash to maintain their population in forest stands or clearings. The influence that surface fuels, i.e. living or dead ground vegetation, have on the risk of fire is clear and has been widely studied (e.g. Agee and Skinner, 2005). The abundance of these fuels increases the probability of fire ignition, and favour an easy spread of surface fires. It determines the intensity of surface fires, and if the understorey height reaches the base of the canopy it can also initiate crown fires (Finney, 1999; Rothermel and Philpot, 1983).

Understorey vegetation may also provide microclimatic conditions that are favourable to spore dispersal and germination, in particular due to an increase in air humidity (e.g. Melampsora larici-populina, Maugard et al., 2000). In contrast, the mildew Erysiphe alphitö̈des requires dry and warm temperatures to develop and is therefore more frequent in low density oak stands (Nageleisen et al., 2002).

Finally, the understorey vegetation may provide a suitable habitat for natural enemies that can control pest insects (Miller and Stephen, 1983; Ross et al., 2005). A large part of the natural enemy fauna, which comprises predators and parasitoids, lives and feeds in the understorey vegetation, hence the importance of maintaining some. It has been shown for example that removing competing vegetation in loblolly pine (Pinus taeda) plantations can reduce total parasitism of the pine tip moth Rhyacionia sp. (McCravy et al., 2001 in Ross et al., 2005).

Management of understorey vegetation may be detrimental to a forest stand's ability to withstand strong winds. Both wind tunnel studies (Gardiner et al., 2005) and field experiments (Wellpott, 2008) in conifer plantations have shown that the presence of an understorey reduces the wind loading to the overstorey trees, and is therefore expected to reduce the risk of windthrow.

\section{THINNING AND PRUNING}

Thinning is the mechanical removal of some trees in a forest stand, in order to enhance the tree growth, vitality, and stem and wood quality of the remaining trees. It is either applied once, or repeatedly, during the period after stand establishment and prior to final harvesting. The type of thinning (frequency, timing, intensity, selection objectives) may change tree species composition and influence the vertical and horizontal structure of the stand. Thinning also creates stumps and dead wood. Pruning is a silvicultural tool to accelerate the otherwise natural loss of branches regulated by stand density. Trees grown at a wide spacing retain more of their branches, and if unpruned, their branches grow thicker, thus reducing the quality and value of the wood through the presence of large knots. Therefore these living branches are removed, normally by saw, from the lower part of the crown.

There are several direct and indirect effects of thinning which influence the risk of pest and pathogen damage. Sunnier conditions may favour insects pests (e.g. Pissodes strobi, Taylor et al., 1996; bark beetles, Fettig et al., 2007) and higher temperatures may lead to a larger number of generations or sister broods in the warm season (voltinism), increasing the risk of damage (Amman, 1973; 1989). Thinning can result in warmer conditions that increase the risk of infections by some pathogens (e.g. H. annosum, Brandtberg et al., 1996; Thor and 
Stenlid, 2005). For this reason, thinning during the winter is recommended, when no air-borne $H$. annosum basidiospores are present (Rönnberg et al., 2006).

Thinning or pruning, living fresh stumps and logging scars, can open several routes for infection by pathogens or attack by pests that can subsequently spread to neighbouring trees (e.g. H. annosum: Korhonen et al., 1998; Piri and Korhonen, 2007; Ronnberg et al., 2006; Armillaria root rot: Legrand et al., 2005; Robinson, 2003). Mechanical injuries during thinning and pruning operations create wounds that provide entry sites for many forest pathogens, such as cankers, stains and rot fungi (Bruhn et al., 2002; Chou and MacKenzie, 1988; Hessburg et al., 2001; Metzler, 1997; Rönnberg, 2000; Zolciak and Sierota, 1997). Several bark beetles such as Ips typographus (Vaupel et al., 1981) and Dendroctonus micans (Grégoire, 1988) and the stem borer Dioryctria sylvestrella (Jactel et al., 1996a; b) are attracted by resin odours released from injured stems after pruning or thinning, and then go on to attack living trees in the vicinity.

When thinning improves individual tree vigour it can reduce tree susceptibility to a number of secondary pests including bark beetles. Scolytids that attack healthy trees are often killed by drowning or immobilization in resin exuded from entry holes; the so-called "constitutive resistance" (Lieutier, 2005). Recently Fettig et al. (2007) thoroughly reviewed the relevance of thinning to prevent and control bark beetle infestations in coniferous forests of North America. By contrast, primary pests which prefer vigorous trees may be favoured by thinning operations as observed with many defoliators (Sierpinski, 1972), the pine processionary moth, T. pityocampa (Speight and Wainhouse), 1989, the pine tip moth Rhyacionia frustrana (Berisford, 1988 in Wainhouse, 2005) and the spruce budworm, Choristoneura pinus (Kouki et al., 1997). Repeated thinning operations in coppice stands (Stanosz and Patton, 1987; Stiell and Berry, 1986) or severe pruning (Hood et al., 2002) resulted in lower individual tree vigour and increased root rot damage.

Thinning also modifies the structure of forest stands. Canopy opening causes the greatest increase in risk of wind damage to forest stands (Quine et al., 1995; Schreiner et al., 1996). This is because a thinned stand, at least for the first 3-5 y after thinning, has increased canopy roughness (Dhôte, 2005; Schutz et al., 2006), which allows the wind to penetrate the canopy, and less wind energy is dissipated by the mechanical contact between crowns (Milne, 1991). In addition, trees that have grown in dense stands are poorly adapted to wind movement and therefore have poor anchorage strength until they can respond to the increased loading by strengthening their stems and root systems (Nicoll and Ray, 1996; Schütz et al., 2006; Stokes et al., 1997). One of the principles of forest fuel reduction treatments is to decrease crown density to reduce crown fire potential. As forest thinning achieves this, it can successfully decrease the potential for fire transmission between adjacent tree crowns (Agee and Skinner, 2005), reducing the probability of tree mortality (González et al., 2007b; Kalabokidis and Omi, 1998; Pollet and Omi, 2002). Shaded fuelbreaks (spatial buffers) which are thinned to reduce crown fuels and treated to reduce surface fuels are com- mon tools to reduce fire risk at a landscape level. A variabledensity thinning combined with both a thinning from below and patch thinning, creates heterogeneity of the canopy that results in a decreased risk of a crown fire spreading (Peterson et al., 2005).

Slash produced by thinning or pruning operations offers a breeding substrate for small bark beetle species such as Ips pini (Gara et al., 1999; Six et al., 2002), Hylastes angustatus or Pityogenes chalcographus (Grodzki, 1997) which can build up their population on woody debris and then attack living trees. Similarly, thinning and pruning may produce an increase of dead surface fuels (slash) that enhance the risk of forest fires (Carey and Shumann, 2003) and decrease the moisture content through increased light and surface wind speed, affecting surface fire behaviour (Fernandes and Rigolot, 2007; Pollet and Omi, 2002). For this reason, management operations that reduce the amount of thinning residues are recommended to make thinning more effective in reducing fire risk (Peterson et al., 2005; Pollet and Omi, 2002).

\section{HARVESTING}

The development of forests managed with the objective of wood production is terminated by harvesting operations, which from a technical point of view, are a sequence of cutting, processing and transport of timber. However logging should also be seen as a silvicultural operation that intervenes in the forest ecosystem and abruptly changes its ecological characteristics. The scale of this impact relates to the applied method of harvesting (clearcut, selective cutting, shelterwood, etc.), its intensity (volume of logged trees), the type of machinery used, the rotation length and yield age, and the time of logging in the season.

The impact of harvesting on the threat from game, insect pests and fungal pathogens mainly results from the provision of food resources or accessible breeding material. In the years after clear-cutting, deer food such as the stems of shrubs, herbs and grasses, increase in abundance and availability (Harlow et al., 1997). Overstorey reduction results in increased; succulent (shrub) browsing by moose (Monthey, 1984), winter browsing (seedlings or saplings) by hare (Harlow et al., 1997), and tree seeds and invertebrate prey for small mammals (Fuller et al., 2004). Similarly Hylobius abietis populations are dependent on the abundance of fresh conifer stumps (Långström and Day, 2002). Felled trees or logging residues can serve as a breeding substrate for many bark beetles such as Ips typographus, Pityogenes chalcographus (Eriksson et al., 2006; Grodzki, 1997; Grodzki et al., 2006) and Ips sexdentatus (Samalens et al., 2007) in conifer forests as well as for a number of scolytids in beech forests (Losekrug, 1988; Petercord, 2005). Likewise, stumps of trees infected by $H$. annosum (Moykkynen and Mina, 2002) or Armillaria sp. (Legrand et al., 2005), and left after final harvesting, represent important infection sources in the following tree generation. By analogy, if no post-harvest fuel treatment (slash removal, bush control, prescribed burning) is undertaken, highly flammable fuel combinations can persist for several years (Weatherspoon and Skinner, 1995). 
The second mechanism that relates harvesting practices to increased biotic risks originates in the mechanical injuries caused by machinery during thinning and pruning operations (see Sect. 7). As a result, harvesting operations can influence the risk to stands established on already harvested areas. Mechanical injuries to roots in the upper soil layers during harvesting and logging also stimulate the spread of Armillaria root disease, by the stimulation of the growth of cut rhizomorphs (Zolciak and Sierota, 1997).

The third main mechanism contributing to the effects of harvesting on forest health relates to the alteration of stand environmental and physical conditions. In stands of deciduous trees, especially those with thin bark such as beech, the effect on tree physiology of suddenly opening stand edges may increase their susceptibility to insect pests (Delb, 2004) and fungal diseases (Klein, 1997). Additionally, the increase of solar radiation and wind circulation at ground level may facilitate the reduction of moisture in dead fuel and facilitate the ignition and fast spread of forest fires (Rothermel and Philpot, 1973; 1983). Clearfelling of a stand will also suddenly expose the edges of nearby stands to the wind, and will therefore increase the wind speeds experienced by the trees, thus increasing the risk of windthrow (Gardiner and Quine, 2000). In partial harvesting, the susceptibility of the remaining trees increases due to a loss of cohesion of the stand. The remaining trees experience more wind, and at the same time they lack mutual support. Rotation lengths influence windthrow risk in two different ways. Firstly, the older the trees get, the taller they become, and thus they will receive higher wind loading and will have a longer "lever-arm" (Mosandl and Felbermeier, 1999; Zimmermann, 1985). Secondly, a longer rotation increases the chance that a severe wind storm will occur during the life of the crop (Quine et al., 1995; Schelhaas et al., 2007). Logging operations with heavy machinery may also result in soil compaction which can in turn trigger pathogen infections. Seedlings of the American chestnut Castanea dentata are more susceptible to Phythophtora cinnamomi infections under conditions of higher soil compaction (Rhoades et al. 2003). Soil compaction may also increase the risk of wind damage through reduction of root anchorage (Andersen, 1954).

\section{GENERAL CONCLUSIONS}

What emerges from this collection of observations and explanations is that forest management substantially affects both the occurrence of many biotic and abiotic hazards and stand susceptibility to these damaging agents that threaten the productivity and the sustainability of forest ecosystems. However the reader may get the impression that different silvicultural operations, and even different options for each operation, will have multiple yet contradictory effects on stand susceptibility to various hazard types. This feeling reflects the complexity of managing forests, which are in fact structurally diverse and perennial ecosystems with an almost infinite number of species and site interactions. It is however unrealistic to search for a single model of forest stand management that would re- duce all of the risks of all types of damage, in a given situation. But fortunately this would never in practice be required as forest managers do not have to deal with such a large diversity of tree species, management options and hazard types. Foresters most commonly have at their disposal a limited number of tree species that will grow in local site conditions, and the regional prevalence of hazards makes it possible to rate the main risks of damage.

However, beyond this case-by-case and step-by-step approach, we believe that it is possible to draw some general conclusions that hold across a wide range of forest conditions. Going back to our explanations of the effects of silvicultural operations and options on hazard occurrence and stand susceptibility, we can identify four main processes that drive these causal relationships (Fig. 2).

Firstly, local microclimate not only has influences on tree physiology and resistance, but also has direct effects on the prevalence of hazards. For example, high temperature and prolonged drought induce physiological stress in trees and at the same time are favourable to the development of pest insects and increase the frequency and severity of fires. Cool and wet conditions are often beneficial to fungal pathogens and of course more frequent strong winds increase the risk of damage. The selection of the site is the prominent decision that will determine in which climatic conditions trees and associated antagonistic species will develop. Other stand management options can also modify forest microclimate, such as the management of understorey cover, through cleaning and regeneration practices, and the density of trees which results from thinning and harvesting regimes.

The second main process which drives hazard occurrence and stand susceptibility, and is affected by silviculture, is the provision of fuel and resources to biotic and abiotic hazards. Trees are not always suitable for herbivore pests and pathogenic fungi due to seasonal and yearly variations in accessibility or palatability. Pest and pathogen species therefore depend on alternative breeding substrates or complementary food resources to survive, such as other canopy or understorey plant species, slash, brash or remaining stumps. Moreover woody debris or understorey vegetation can fuel forest fires. Every silvicultural operation that can reduce such reservoirs of alternative food and supplementary fuel would then decrease stand susceptibility to biotic and abiotic risks. For example the availability of alternative host plants greatly depends on site selection and preparation, stand composition, regeneration and cleaning practices. The abundance of breeding substrates, such as stumps and slash, are highly dependant on the frequency and intensity of thinning, pruning and harvesting. The amount of fuel for forest fires mainly depends on the effectiveness of residue removal through adapted decisions about site preparation, cleaning, thinning, pruning and harvesting options. Conversely, changing stand composition may represent an effective way of limiting the accessibility of food resources to pests and pathogens, with non-host tree species developing physical or chemical barriers.

The third main process only accounts for biotic hazards as it deals with maintenance or enhancement of biological control by the natural enemies. These biocontrol agents need shelter, 


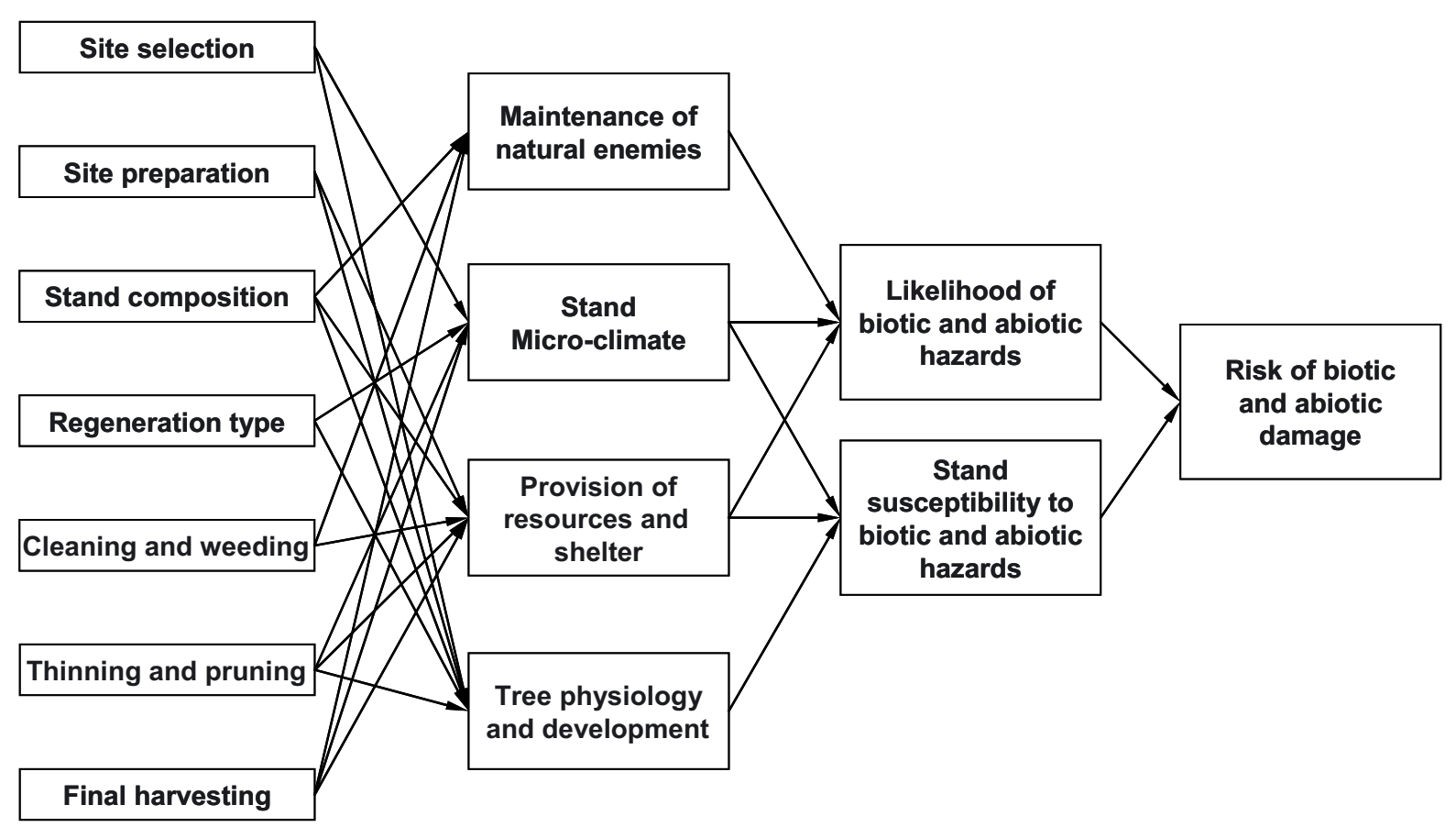

Figure 2. Summary diagram of key relationships between silvicultural operations and processes driving biotic and abiotic hazards likelihood and forest stand susceptibility that determine risk of damage.

complementary food resources or breeding substrates to persist on site. As a consequence, natural enemies may be affected by the same silvicultural operations as their host or prey. Control is optimised when for a given silvicultural operation the choice of an option results in a reduction in numbers of a particular pest and an increase in its natural enemies. Associations of certain tree species can reduce the accessibility of herbivorous insects to their host trees, while providing complementary habitats and resources for their predators. In contrast changing site preparation, cleaning, thinning, pruning or harvesting practices with the aim of reducing the woody debris that are used for shelter, or as a breeding substrate, by pests and pathogens, can also reduce the abundance of microhabitats for their natural enemies. Resolving such contradictions will obviously require management compromises.

Lastly, individual tree physiology and development is the main factor in resistance to a range of hazards. The palatability of tree tissues, the amount of secondary metabolites, and the phenology of growth, are main drivers of tree susceptibility to mammal grazers, pest insects and pathogenic fungi. The size and shape of trees, and their root development, are particularly important in predicting resistance to strong winds. The water and biochemical content of tree component parts also determine tree inflammability. All of these individual attributes depend on tree phenotype which depends on the interaction between genotype and local environment. Site preparation, stand composition, the type of regeneration, and the thinning regime can all greatly influence individual tree growth and metabolism, and thus modify their susceptibility to biotic and abiotic hazards. It is important here to remember that optimizing tree growth will not necessarily improve tree resistance as some primary pests and diseases may develop better on vigorous trees, and similarly, the most productive stands may be more vulnerable to strong winds and fire hazards.

In conclusion, silvicultural operations have multiple, sometimes contradictory, effects on hazard likelihood and stand susceptibility to these damaging agents. Forest management is therefore, above all, a question of compromises, where one has to balance risks and benefits not only for every silvicultural operation but also for their possible interactions or cascading effects. Given the limited set of options that are at managers' disposal, it may be almost impossible at the stand level to find the correct balance. However, one way to circumvent these difficulties, while keeping forest multifunctionality in perspective, is to consider management at a larger scale, i.e. at the landscape level where it is possible to spread the risk by combining stands with different composition and management, such as intensively managed stands interspersed with natural forest remnants.

Acknowledgements: We are very grateful to Claudia Antoniotti and Inge Van Halder for editing the references. This work was supported under the EU funded FP6 EFORWOOD-IP project (contract 518128).

\section{REFERENCES}

Agee J.K. and Skinner C.N., 2005. Basic principles of forest fuel reduction treatments. For. Ecol. Manage. 211: 83-96.

Agee J.K., 1993. Fire ecology of pacific northwest forests, Island Press, Washington D.C., 493 p.

Agee J.K., Bahro B., Finney M.A., Omi P.N., Sapsis D.B., Skinner C.N., van Wagtendonk J.W., and Weatherspoon C.P., 2000. The use of shaded fuelbreaks in landscape fire management. For. Ecol. Manage. 127: 56-66. 
Amman G.D., 1973. Population changes of the mountain pine beetle in relation to elevation. Environ. Entomol. 2: 541-547.

Amman G.D., 1989. Why partial cutting in lodgepole pine stands reduce losses to mountain pine beetle, GTR-INT-262, U.S. department of agriculture, forest service, intermountain research station, Ogden UT, $12 \mathrm{p}$.

Andersen K.F., 1954. Gales and gale damage to forests, with special reference to the effects of the storm of 31st, January 1953, in the northeast of Scotland. Forestry 27: 97-121.

Anglberger H. and Halmschlager E., 2003. The severity of Sirococcus shoot blight in mature Norway spruce stands with regard to tree nutrition, topography and stand age. For. Ecol. Manage. 177: 221-230.

Baier P., Pennerstorfer J., and Schopf A., 2007. Phenips - A comprehensive phenology model of Ips typographus (L.) (Col. Scolytidae) as a tool for hazard rating of bark beetle infestation. For. Ecol. Manage. 249: 171-186.

Baltensweiler W. and Fischlin A., 1988. The larch budmoth in the Alps. Chapter 17. In: Berryman, A.A. (Ed.), Dynamics of forest insect populations: patterns, causes, implications, Plenum, New York, pp. 331-351.

Barbaro L., Couzi L., Bretagnolle V., Nezan J., and Vetillard F., 2007. Multi-scale habitat selection and foraging ecology of the eurasian hoopoe (Upupa epops) in pine plantations, Biodivers. Conserv. (in press).

Barre F., Milsant F., Palasse C., Prigent V., Goussard F., and Geri C., 2002. Preference and performance of the sawfly Diprion pini on hos and non-host plants of the genus Pinus. Ent. Exp. App. 102: 229-237.

Barthod C., 1995. Sylviculture et risques sanitaires dans les forêts tempérées $-2^{\mathrm{e}}$ partie. Rev. For. Fr. 47: 39-53.

Berthelot A., Bastien C., Villar M., Pinon J., Heois B., Bourlon V., and Menard M., 2005. Le GIS Peuplier, 4 ans après sa création. In: Informations - forêt, Afocel No. 708, 6 p.

Bigger M., 1985. The effect of attack by Amblypelta cocophaga (Hemiptera: Coreidae) on growth of Eucalyptus deglupta in the Solomon Islands. Bull. Ent. Res. 75: 595-608.

Björklund N., Nordlander G., and Bylund H., 2003. Host-plant acceptance on mineral soil and humus by the pine weevil Hylobius abietis (L.). Agric. For. Entomol. 5: 61-65.

Black H.C., 1992. Silvicultural approaches to animal damage management in pacific Northwest forests. PNW-GTR-287, U.S. department of Agriculture, Forest Service, Pacific NW Research Station, Portland, Oregon, 439 p.

Blennow K. and Sallnas O., 2002. Risk perception among non-industrial private forest owners. Scand. J. For. Res. 17: 472-479.

Blodgett J.T., Herms D.A., and Bonello P., 2005. Effects of fertilization on red pine defence chemistry and resistance to Sphaeropsis sapinea. For. Ecol. Manage. 208: 373-382.

Bond W.J. and Van Wilgen B.W., 1996. Why and how do ecosystems burn? Fire and Plants, Chapman \& Hall, London, pp. 17-33.

Brandeis T.J., Newton M., and Cole E.C., 2002. Biotic injuries on conifer seedlings planted in forest understory environments. New For. 24: $1-14$.

Brandtberg P. O., Johansson M., and Seeger P., 1996. Effects of season and urea treatment on infection of stumps of Picea abies by Heterobasidion annosum in stands on former arable land. Scan. J. For. Res. 11: 261-268.

Brasier C.M., Beales P.A., Kirk S.A., Denman S., and Rose J., 2005. Phytophthora kernoviae sp. nov., an invasive pathogen causing bleeding stem lesions on forest trees and foliar necrosis of ornamentals in the UK. Mycol. Res. 109: 853-859.
Bruhn J.N., Wetteroff J.J., Jr. Mihail J.D., Jensen R.G., and Pickens J.B., 2002. Harvest-associated disturbance in upland Ozark forests of the Missouri Ozark forest ecosystem project. GTR-NC-227, U.S. Department of Agriculture, Forest Service, North Central Research Station, pp. 130-146.

Bryndum H., 1986. Influence of silvicultural treatment of crops on the risk of windblow. Minimizing Wind Damage to Coniferous Stands. Proceedings of the workshop organized jointly by the Danish forest experiment station and the commission of the european communities at Løvenholm Castle, Denmark, March 3-7 (ed. Communities, CotE), Løvenholm Castle, Denmark, 35 p.

Caldeira M.C., Fernandez V., Tome J., and Pereira J.S., 2002. Positive effect of drought on longicorn borer larval survival and growth on eucalyptus trunks. Ann. For. Sci. 59: 99-106.

Cameron A.D., 2002. Importance of early selective thinning in the development of long-term stand stability and improved log quality: a review. Forestry 75: 25-35.

Camy C., Dreyer E., Delatour C., and Marcais B., 2003. Responses of the root rot fungus Collybia fusipes to soil waterlogging and oxygen availability. Mycol. Res. 107: 1103-1109.

Capecki Z., Grodzki W., and Zwoliński A., 1989. Gradacja wskaźnicy modrzewianeczki Zeiraphera griseana Hb. (Lepidoptera, Tortricidae) w Polsce a latach 1997-1983, Prace Inst. Bad. Leś. 688/690: 95-152.

Carey H. and Schumann M., 2003. Modifying wildfire behaviour - the effectiveness of fuel treatments: the status of our knowledge, national community forestry center, southwest region working paper, $31 \mathrm{p}$.

Carrow J.R. and Betts R.E., 1973. Effects of different foliar-applied nitrogen fertilisers on balsam woody aphid. Can. J. For. Res. 3: 122-139.

Chou C.K.S. and MacKenzie M., 1988. Effect of pruning intensity and season on Diplodia pinea infection of Pinus radiata stem through pruning wounds. Eur. J. For. Path. 18: 437-444.

Colin, F., Brunet, Y., Vinkler, I., and Dhôte, J.F., 2008. Résistance aux vents forts des peuplements forestiers, et notamment des mélanges d'espèces. Rev. For. Fr. LX: 191-201.

Coutts M.P., Nielsen C.N., and Nicoll B.C., 1999. The development of symmetry, rigidity and anchorage in the structural root system of conifers. Plant Soil 217: 1-15.

Delb H., 2004. Rindenbrüter an Buche. In: FVA Waldschutzinfo, Vol. 2004, FVA Baden, Württemberg.

Demolin G., 1969. Comportement des adultes de Thaumetopoea pityocampa Schiff. Dispersion spatiale, importance écologique. Ann. Sci. For. 26: 81-102.

Desprez-Loustau M.L. and Wagner K., 1997a. Components of maritime pine susceptibility to twisting rust - A path coefficient analysis. Eur. J. Plant. Pathol. 103: 653-665.

Desprez-Loustau M.L. and Wagner K., 1997b. Influence of silvicultural practices on twisting rust infection and damage in maritime pine, as related to growth. For. Ecol. Manage. 98: 135-147.

Desprez-Loustau M.L., Marcais B., Nageleisen L.M., Piou D., and Vannini A., 2006. Interactive effects of drought and pathogens in forest trees. Ann. For. Sci. 63: 597-612.

Dhôte J.F., 2005. Implication of forest diversity in resistance to strong winds. In: Scherer-Lorenzen M., Körner C., and Schulze E.D. (Eds), Forest diversity and function - temperate and boreal systems, Springer Verlag. Ecological studies 176: 291-308.

Dickson J.G., 1979. Seasonal population of insectivorous birds in mature bottomland hardwood forest in south Louisiana. In: Dickson J.G., Connor R.N., Fleet R.R., Jackson J.A., and Kroll J.C. (Eds), The role of insectivorous birds in forest ecosystems, Academic Press, New York, pp. 261-269. 
Dimitrakopoulos A.P. and Papaioannou K.K., 2001. Flammability assessment of Mediterranean forest fuels. Fire Technol. 37: 143-152.

Dini-Papanastasi O., 2008. Effects of clonal selection on biomass production and quality in Robinia pseudoacacia var. monophylla Carr. For Ecol. Manage. 256: 849-854.

Dungey H.S., Potes B.M., Carnegie A.J., and Ades P.K., 1997. Mycosphaerella leaf disease: genetic variation in damage to Eucalyptus nitens, Eucalyptus globulus, and their F-1 hybrid. Can. J. For. Res. 27: 750-759.

Elek J.A., 1997. Assessing the impact of leaf beetles in eucalyptus plantations and exploring options for their management. Tasforests 9: 139-154.

Emmingham W.H., Bondi M., and Hibbs D.E., 1989. Underplanting western hemlock in a red alder thinning: early survival, growth and damage. New For. 3: 31-43.

Eriksson M., Lilja S., and Roininen H., 2006. Dead wood creation and restoration burning: implications for bark beetles and beetle induced tree deaths. For. Ecol. Manage. 231: 205-213.

FAO, 2007. state of the world's forests 2007. Food and Agricultural Organization of the United Nations, Rome, $144 \mathrm{p}$.

Fedorov N.J. and Poleschuk J.M., 1981. Conifer root rot studies in the USSR for the years 1976-1978. Eur. J. For. Pathol. 11: 44-50.

Fernandes P.M. and Rigolot E., 2007. The fire ecology and management of maritime pine (Pinus pinaster Ait.). For. Ecol. Manage. 241: 1-13.

Fettig C.J., Klepzig K.D., Billings R.F., Munson A.S., Nebeker T.E., Negrón J.F., and Nowak J.T., 2007. The effectiveness of vegetation management practices for prevention and control of bark beetle infestations in coniferous forests of the western and southern United States. For. Ecol. Manage. 238: 24-53.

Finke D.L. and Denno, R.F., 2002. Intraguild predation diminished in complex-structured vegetation: implications for prey suppression. Ecology 83: 643-652.

Finney M.A., 1999. Mechanistic modelling of landscape fire patterns. In: Mladenoff D.J. and Baker W.L. (Eds), Spatial modelling of forest landscape change: approaches and applications, Cambridge University press, Cambridge UK, pp. 186-209.

Frutos R. Rang C., and Royer M., 1999. Managing insect resistance to plants producing Bacillus thuringiensis toxins. Crit. Rev. Biot. 19: 227-276.

Führer E. and Nopp U., 2001. Ursachen, Vorbeugung und Sanierung von Waldschäden, Facultas, Vienna, Austria, 514 p.

Fuller A.K., Harrison D.J., and Lachowski H.J., 2004. Stand scale effects of partial harvesting and clearcutting on small mammals and forest structure. For. Ecol. Manage. 191: 373-386.

Gara R. I., Millegan D.R., and Gibson K.E., 1999. Integrated pest management of Ips pini (Col., Scolytidae) populations in south-eastern Montana. J. Appl. Entomol. 123: 529-534.

Gardiner B., Marshall B., Achim A., Belcher R., and Wood C., 2005. The stability of different silvicultural systems: a wind tunnel investigation. Forestry 78, 471-484.

Gardiner B.A. and Quine C.P., 2000. Management of forests to reduce the risk of abiotic damage - a review with particular reference to the effects of strong winds. For. Ecol. Manage. 135: 261-277.

Gerlach J.P., Reich P.B., Puettman K., and Baker T., 1997. Species, diversity, and density affect tree seedling mortality from Armillaria root rot. Can. J. For. Res. 27: 1509-1512.

Germishuizen P.J., 1984. Rhizina undulata, a pine seedling pathogen in southern Africa. In: Grey D.C., Schönau A.P.G., Schutz C.J., and Van Laar A. (Eds.), Symposium on site and productivity of fast growing plantations, Pretoria and Pietermaritzburg, South Africa, pp. 753-765.
Gibbs J.N., Greig B.J.W., and Pratt J.E., 2002. Fomes root rot inany given site. Although some of the slightly infected thetford forest, East Anglia: Past, present and future trees in crown condition. Forestry 75 : 191-202.

González J.R., Palahí M., Trasobares A., and Pukkala, T., 2006. A fire probability model for forest stands in Catalonia (north-east Spain). Ann. For. Sci. 63: 169-176.

González J.R. and Pukkala T., 2007. Characterization of wildfire events in Catalonia (north-east Spain). Eur. J. For.Res. 126: 421-429.

González J.R., Kolehmainen O., and Pukkala T., 2007a. Using expert knowledge to model forest stands vulnerability. Comput. Electron. Agric. 55: 1007-114.

González J.R., Trasobares A., Palahí M., and Pukkala T., 2007b. Predicting tree survival in burned forests in Catalonia (North-East Spain) for strategic forest planning. Ann. For. Sci. 64: 733-742.

Grégoire J-C., 1988. The greater European spruce beetle. In: Berryman A.A. (Ed.), Dynamics of forest insect populations: patterns, causes, implications, Plenum Press, New York, pp. 455-478.

Grodzki W., 1997. Pityogenes chalcographus (Coleoptera, Scolytidae) - an indicator of man-made changes in Norway spruce stands, Biológia, Bratislava 52: 217-220.

Grodzki W., Jakuš R., Lajzová E., Sitková Z., Mźczka T., and Skvarenina J., 2006. Effects of intensive versus no management strategies during an outbreak of the bark beetle Ips typographus (L.) (Col.: Curculionidae, Scolytinae) in the Tatra Mts. in Poland and Slovakia. Ann. For. Sci. 63: 55-61.

Grodzki W., Kosibowicz M., and Jachym M., 1999. Różnorodność biologiczna ekosystemów a problemy ochrony lasów górskich. Sylwan 143: 21-31.

Gruppe A., Fußede, M., and Schopf R., 1999. Short-rotation plantations of balsam poplar and aspen on former arable land in the Federal Republic of Germany: Defoliation insects and leaf constituents. For. Ecol. Manage. 121: 113-122.

Guibert B., Maizeret C., Ballon P., and Montes E., 1992. Influence of forest management on roe deer populations in the Landes of Gascony. In: Proceedings of the international symposium "Ongulés/Ungulates 91”, Toulouse, France, September 2-6, 1991, pp. 617-620.

Harfouche A., Baradat P., and Kremer A., 1995. Intraspecific variability in maritime pine (Pinus pinaster) in the south-east of France. II. Heterosis and combination of characters in interracial hybrids. Ann. Sci. For. 52: 329-346.

Harju A. and Tahvanainen J., 1997. Palatability of silver birch seedlings to root voles Microtus oeconomus. Ecography 20: 83-87.

Harlow R.F., Downing R.L., and van Lear D.H., 1997. Responses of wildlife to clearcutting and associated treatments in the Eastern United States, Technical paper No 19, Department of Forest Resources, Clemson University.

Heimburger C., 1962. Breeding for disease resistance in forest trees. For. Chron. 38: 356-362.

Hély C., Flannigan M., and Bergeron Y., 2003. Modeling Tree Mortality Following Wildfire in the Southeastern Canadian mixed-wood boreal forest. For. Sci. 49: 566-576.

Herms D.A., 2002. Effects of fertilization on insect resistance of effect of nitrogen on disease development and gene expression in woody ornamental plants: reassessing an entrenched paradigm. Environ. Entomol. 31: 923-933.

Hessburg P.F., Goheen D.J., and Koester H., 2001. Association of black stain root disease with roads, skid trails, and precommercial thinning in Southwest Oregon. Western J. Appl. For. 16: 127-135.

Heybroek H.M., 1982. Monoculture versus mixture: interactions between susceptible and resistant trees in mixed stand. In: Heybroek H.M., Stephan B.R., and von Weissenberg K. (Eds), Resistance to disease and pest in forest trees, Centre for Agricultural Publishing and Documentation, Wageningen, pp. 326-341. 
Highsmith M.T., Frampton J., O'Malley D., Richmond J., and Webb M., 2001. Susceptibility of parent and interspecific F1 hybrid pine trees to tip moth damage in a coastal North Carolina planting. Can. J. For. Res. 31: 919-923.

Hlásny T. and Turčání M., 2008. Insect pests as climate change driven disturbances in forest ecosystems, bioclimatology and natural hazards, Springer Verlag (in press).

Holmsgaard E., 1986. Historical development of wind damage in conifers in Denmark. In: minimizing wind Damage to coniferous stands. Proceedings of the workshop organized jointly by the Danish Forest Experiment Station and the Commission of the European Communities at Løvenholm Castle, Denmark, March 3-7 (Ed. Communities, CotE), Løvenholm Castle, Denmark.

Hood I.A., Kimberley M.O., Gardner J.F., and Sandberg C.J., 2002. Armillaria root disease of Pinus radiata in New Zealand. 3: Influence of thinning and pruning. N. Z. J. For. Sci. 32: 116-132.

Hougardy E. and Grégoire J.C., 2000. Spruce stands provide natural food sources to adult hymenopteran parasitoids of bark beetles. Entomol. Exp. Appl. 96: 253-263.

Huss J. and Olberg-Kalfass R., 1982. Unerwunschte Wechselwirkungen zwischen Unkrautbekämpfungen und Rehwildshäden in Fichtenkulturen. Allg. Forstz. 37: 1329-1331.

Jactel H. and Brockerhoff E., 2007. Tree diversity reduces herbivory by forest insects. Ecol. Lett. 10: 835-848.

Jactel H., Brockerhoff E., and Duelli P., 2005. A test of the biodiversitystability theory: meta-analysis of tree species diversity effects on insect pest infestations, and re-examination of responsible factors. In: Scherer-Lorenzen M., Körner C., and Schulze E.-D. (Eds), Forest diversity and function - temperate and boreal systems, Springer Verlag. Ecological studies 176: 235-262.

Jactel H., Menassieu P., and Kleinhentz M., 1996. Vigour increases the susceptibility of the maritime pine to attack by Dioryctria sylvestrella. In: Calatayud P.A. and Vercambre B. (Eds.), Insect and plant interactions, papers of the fifth meeting of the working group on insect and plant relations, 26-27 October 1995, Montpellier, France, pp. 82-84.

Jactel H., Menassieu P., Vétillard F., Gaulier A., Samalens J.C., and Brockenhoff E.G., 2006. Tree species diversity reduces the invasibility of maritime pine stands by the bast Matsucoccus feytaudi (Homoptera: Margarodidae). Can. J. For. Res. 36:314-323.

Jactel H., Branco M., Gonzalez-Olabarria J.R., Grodzki W., Långström B., Moreira F., Netherer S., Nicoll B.C, Orazio C., Piou D., Santos H., Schelhaas M.J., Tojic K., and Vodde F., 2008. Forest stands management and vulnerability to biotic and abiotic hazards, EFORWOOD report PD 243, 88 p. http://87.192.2.62/Eforwood/ Portals/0/documents/D2.4.3_FINAL_toAK20080707.pdf

Johansson M. and Marklund E., 1980. Antagonists of Fomes annosus in the rhizosphere of grey alder (Alnus incana) and Norway spruce (Picea abies). Eur. J. For. Pathol. 10: 385-396.

Kalabokidis K.D. and Omi P.N., 1998. Reduction of fire hazard through thinning/residue disposal in the urban interface. Int. J. Wildl. Fire. 8: 29-35.

Karlman, M., Hansson P., Witzell J., 1994. Scleroderris canker on Lodgepole pine introduced in Northern Sweden. Can. J. For. Res. 24: 1948-1959.

Klein E., 1997. Buchenkrebse in Jungwuchsen und Buchen- 'T-Krebse'. Forst. Holz 52: 58-61.

Kleinhentz M., Raffin A., and Jactel H., 1998. Genetic parameters and gain expected from direct selection for resistance to Dioryctria sylvestrella Ratz. (Lepidoptera: Pyralidae) in Pinus pinaster Ait., using a full diallel mating design. For. Genet. 5: 147-154.

Korhonen K., Delatour C., Greig B.J.W., and Schönhar S., 1998. Silvicultural control. In: Woodward S., Stenlid J., Karjalainen R., and Hüttermann A. (Eds.), Heterobasidion annosum. Biology, ecology, impact and control, CAB International, Cambridge, 589 p.
Kouki J., McCullough D.G., and Marshall L.D., 1997. Effect of forest stand and edge characteristics on the vulnerability of jack pine stands to jack pine budworm (Choristoneura pinus) damage. Can. J. For. Res. 27: 1765-1772.

Kraus J.F., 1986. Breeding shortleaf $\times$ loblolly pine hybrids for the development of fusiform rust-resistant loblolly pine. South. J. Appl. For. 10: 195-197,

Kron W., 2002. Flood risk $=$ hazard $\times$ exposure $\times$ vulnerability. In: Wu M. et al. (Eds.), Flood defence, Science Press, New York, pp. 82-97.

Kytö M., 1999. Impact of forest fertilization on the vitality and pest resitance of conifers, Finnish Forest Research Institute, Vantaa Research Institute, Research Papers, 742, 40 p.

Kytö M., Niemelä P., and Annila E., 1996a. Vitality and bark beetle resistance of fertilized Norway spruce. For. Ecol. Manage. 84: 149-157.

Kytö M., Niemelä P., and Larsson S., 1996b. Insects on trees: population and individual response to fertilization. Oikos 75: 148-159.

Laiho O., 1987. Metsiköiden alttius tuulituholle Etelä-Suomessa. Susceptibility of forest stands to windthrow in southern Finland, Folia forestalia, Metsaentutkimuslaitos, Helsinki, 706 p.

Landmann G., 1998. Forest health, silviculture and forest management. In: Montoye R. (Ed.), Problemas sanitarios en los sistemas forestales: de los espacios protegidos a los cultivados rapido, Coleccion technica, organismo autonomo parques nacionales, Madrid, pp. 155-183.

Långström B. and Day K.R., 2002. Damage, control and management of weevil pests, especially Hylobius abietis. In: Lieutier F., Day K.R., Battisti A., Grégoire J.C., and Evans H.F. (Eds), Bark and wood boring insects in living trees in Europe, a synthesis, Kluwer Academic Press, Dordrecht, Boston, London, pp. 415-444.

Larsson S. and Tenow O., 1984. Areal distribution of a Neodiprion sertifer outbreak on Scots pine as related to stand condition. Holarc. Ecol. 7: 81-90.

Legrand P., Lung-Escarmant B., and Guillaumi J.J., 2005. Lutte contre l'armillaire en forêts: méthodes sylvicoles et culturales. In: Guillaumin J.J. (Ed.), L'armillaire et le pourridié-agaric des végétaux ligneux, synthèses INRA, pp. 349-364.

Lekes V. and Dandul I., 2000. Using airflow modelling and spatial analysis for defining wind damage risk classification (WINDARC). For. Ecol. Manage. 135: 331-344.

Linden M. and Vollbrecht G., 2002. Sensitivity of Picea abies to butt rot in pure stands and in mixed stands with Pinus sylvestris in southern Sweden. Silva Fenn. 36: 767-778.

Linder P., Jonsson P., and Niklasson M., 1998. Tree mortality after prescribed burning in an old-growth Scots pine forest in northern Sweden. Silva Fenn. 32: 339-349.

Lof M., Paulsson R., Rydberg D., and Welander N.T., 2005. The influence of different overstory removal on planted spruce and several broadleaved tree species: Survival, growth and pine weevil damage during three years. Ann. For. Sci. 62: 237-244.

Lopez-Upton J., White T.L., and Huber D.A., 2000. Species differences in early growth and rust incidence of loblolly and slash pine. For. Ecol. Manage. 132: 211-222.

Loreau M., Naeem S., Inchausti P., Bengtsson J., Grime J.P., Hector A., Hooper D.U., Husto, M.A., Raffaelli D., Schmid B., Tilman D., and Wardle D.A., 2001. Biodiversity and ecosystem functioning: Current knowledge and future challenges. Science 294: 804-808.

Losekrug R.G., 1988. Befall von Buchenalthölzern durch den Laubnutzholzborkenkäfer. Allg. Forstz. 34: 942-943.

Lung-Escarmant B., Guyon D., Chauvin B., Courrier G., and Germain R., 1997. Spatial and temporal pattern of Armillaria root disease in a Pinus pinaster plantation: Incidence of understorey clearing. In: Ninth international conference on Root and Butt Rots, IUFRO working party S2.06.01, Carcans, France, pp. 439. 
Lüpke B. and Spellmann H., 1997. Aspekte der Stabilität und des Wachstums von Mischbestanden aus Fichte und Buche als Grundlage für waldbauliche entscheidungen. Forstarchiv 68: 167-179.

MacDonald A.C., Borralho N.M.G., and Potts B.M., 1997. Genetic variation for growth and wood density in Eucalyptus globulus ssp. globulus in Tasmania (Australia). Silvae Genet. 46: 236-241.

Major E.J., 1990. Water stress in Sitka Spruce and its effect on the green spruce aphid Elatobium abietinum. In: Watt A.D., Leather S.R., Hunter M.D. and Kidd N.A.C. (Eds.), Population dynamics of forest insects, Intercept Ltd, Andover, pp. 85-94.

Maloney P.E., Lynch S.C., Kane S.F., Jensen C.E., and Rizzo D.M., 2005. Establishment of an emerging generalist pathogen in redwood forest communities. J. Ecol. 93: 899-905.

Marchisio C., Cescatti A. and Battisti A., 1994. Climate, soils and Cephalcia arvensis outbreaks on Picea abies in the Italian Alps. For. Ecol. Manage. 68: 375-384.

Markalas S., 1989. Influence of soil moisture on the mortality, fecundity and diapause of the pine processionary moth (Thaumetopoea pityocampa Schiff.). J. Appl. Entomol. 107: 211-215.

Mason W.L., 2002. Are irregular stands more windfirm? Forestry 75: $347-355$.

Mattila U., 2002. The risk of pine twisting rust damage in young Scots pines: a multilevel logit model approach. For. Ecol. Manage. 165: $151-161$.

Mattila U., 2005. Probability models for pine twisting rust (Melampsora pinitorqua) damage in Scots pine (Pinus sylvestris) stands in Finland. For. Path. 35: 9-21.

Mattson W.J., Kuokkanen K., Niemela P., Julkunen-Tiitto R., Kellomaki S., and Tahvanainen J., 2004. Elevated CO2 alters birch resistance to Lagomorpha herbivores. Glob. Chang. Biol. 10: 1402-1413.

Maugard F., Renaud J.P., Villebonne D.d., and Pinon J., 2000. Principaux résultats de l'enquête nationale sur la rouille du peuplier à Melampsora larici-populina Kleb. In: Les Cahiers du département de la santé des forêts No 1, DGFAR - Ministère de l'Agriculture et de la Forêt, France, pp. 40-45.

McCracken, A.R., Dawson, W.M., 1997. Growing clonal mixtures of willow to reduce effect of Melampsora epitea var. epitea source: Eur. J. For. Pathol. 27: 319-329 .

MCPFE, 2002. Improved Pan-European indicators for sustainable forest management, as adopted by the MCPFE expert level meeting Vienna, Austria.

Mermoz M., Kitzberger T., and Veblen T.T., 2005. Landscape influences on occurrence and spread of wildfires in Patagonian forests and shrublands. Ecology 86: 2705-2715.

Metzler B., 1997. Quantitative assessment of fungal colonization in Norway spruce after green pruning. Eur. J. For. Pathol. 27: 1-11.

Miller F.D.Jr. and Stephen F.M., 1983. Effects of competing vegetation on Nantucket pine tip moth (Lepidoptera: Tortricidae) populations in loblolly pine plantations in Arkansas. Environ. Entomol. 12: 101-105.

Milne R., 1991. Dynamics of swaying of Picea sitchensis. Tree Physiol. 9: 383-399.

Miot S., Frey P., and Pinon J., 1999 Varietal mixture of poplar clones: Effects on infection by Melampsora larici-populina and on plant growth Eur. J. For. Pathol. 29: 411-423.

Mitchell S.J., 2003. Effects of mechanical stimulus, shade, and nitrogen fertilization on morphology and bending resistance in Douglas-fir seedlings. Can. J. For. Res. 33: 1602-1609.

Monthey R.W., 1984. Effects of timber harvesting on ungulates in Northern Maine. J. Wildl. Manage. 48: 279-285.
Moreira F., Rego F.C., and Ferreira P.G., 2001. Temporal (1958-1995) pattern of change in a cultural landscape of northwestern Portugal: implications for fire occurrence. Landsc. Ecol. 16: 557-567.

Morrison D. J. and Mallett K., 1996. Silvicultural management of Armillaria root disease in Western Canadian forests. Can. J. Plant. Pathol. 18: 194-199.

Mosandl R. and Felbermeier B., 1999. Auf dem Weg zum naturnahen Wald. Towards close-to-nature forest [in Bayern, Germany]. AFZ/Der Wald 54: 910-914.

Mouillot F., Ratte J.P., Joffre R., Moreno J.M., and Rambal S., 2003. Some determinants of the spatio-temporal fire cycle in a Mediterranean landscape (Corsica, France). Landsc. Ecol. 18: 665674.

Moykkynen T. and Mina J., 2002. Optimizing the management of a buttrotted Picea abies stand infected by Heterobasidion annosum from the previous rotation. Scand. J. For. Res. 17: 47-52.

Murray D.I.L., 1987. Rhizosphere microorganisms from the Jarrah forest of Western Australia and their effects on vegetative growth and sporulation in Phytophthora cinnamomi sands. Aust. J. Bot. 35: 567-586.

Muzika R.M. and Liebhold A.M., 2000. A critique of silvicultural approaches to managing defoliating insects in North America. Agric. For. Entomol. 2: 97-105.

Nageleisen L.M., Pinon J., Frey P., Marcais B., Frochot H., Ningre F., Wehrlen L., and Renaud J.P., 2002. Végétation accompagnatrice et agresseurs biotiques. Revue For. Fr. LIV: 577-584.

Netherer S. and Führer E., 1999. Assessment of the predisposition of forest sites and stands to epidemics of the Little Spruce Sawfly, Pristiphora abietina (Christ) (Hym. Tenthr.). Allg. Forst. Jagdztg. 170: 53-60.

Netherer S. and Nopp-Mayr U., 2005. Predisposition assessment systems (PAS) as supportive tools in forest management - Rating of site and stand-related hazards of bark beetle infestation in the High Tatra Mountains as an example for system application and verification. For. Ecol. Manage. 207: 99-107.

Neuhauser C., Andow D.A., Heimpel G.E., May G., Shaw R.G., and Wagenius S., 2003. Community genetics: expanding the synthesis of ecology and genetics. Ecology 84: 545-558.

Ni Dhubhain A., Walshe J., Bulfin M., Keane M., and Mills P., 2001. The initial development of a windthrow risk model for Sitka spruce in Ireland. Forestry 74: 161-170.

Nicoll B.C. and Ray D., 1996. Adaptive growth of tree root systems in response to wind action and site conditions. Tree Physiol. 16: 891898.

Nicoll, B.C., Easton, E.P., Milner, A.D., Walker, C., and Coutts, M.P. 1995. Wind stability factors in tree selection: distribution of biomass within root systems of Sitka spruce clones. In: M.P. Coutts and J. Grace (Eds.), Wind and trees, Cambridge University press, Cambridge, pp. 276-292.

Nicoll B.C., Gardiner B.A., Rayner B., and Peace A.J., 2006. Anchorage of coniferous trees in relation to species, soil type and rooting depth. Can. J. For. Res. 36: 1871-1883.

Nordlander G., Bylund H., Örlander G., and Wallertz K., 2003. Pine weevil population density and damage to coniferous seedlings in a regeneration area with and without shelterwood. Scand. J. For. Res. 18: $438-448$.

Nowak J.T., Harrington T.B., and Berisford C.W., 2003. Nantucket pine tip moth development and population dynamics: influence of nitrogen fertilization and vegetation control. For. Sci. 49: 731-737.

Offergeld J.P., 1986. The consequences of the tempest of November 1984 on the forest. In: Minimizing wind damage to coniferous stands, 
Proceedings of the workshop organized jointly by the Danish Forest Experiment Station and the Commission of the European communities at Løvenholm Castle, Denmark, March 3-7 (Ed. Communities, CotE), Lovenholm Castle, Denmark, pp. 21-26.

O'Hanlon-Manners D.L. and Kotanen P.M., 2004. Evidence that fungal pathogens inhibit recruitment of a shade-intolerant tree, white birch (Betula papyrifera), in understory habitats. Oecologia 140: 650-653.

Omi P.N. and Martinson. E.J., 2004. Effectiveness of thinning and prescribed fire in reducing wildfire severity. In: Murphy D.D., and Stine P.A. (Eds.), Proceedings of the Sierra Nevada science symposium: Science for Management and Conservation, GTR-PSW-193, U.S. Department of Agriculture, Forest Service, Pacific Southwest Research Station Albany, California, pp. 87-92.

Örlander G. and Nordlander G., 2003. Effects of field vegetation control on pine weevil (Hylobius abietis) damage to newly planted Norway spruce seedlings. Ann. For. Sci. 60: 667-671.

Örlander G., Nordlander G., and Wallertz K., 2001. Extra food supply decreases damage by the pine weevil Hylobius abietis. Scand. J. For. Res. 16: 450-454.

Oxenham R., 1983. A study on the effect of competing vegetation and browsing on early plantation performance. N. S. Dept. of Lands and Forests, Forest Tech. Note No. 5, 6 p.

Pasquier-Barre F., Géri C., Goussard F., Auger-Rozenberg M.A., and Grenier S., 2000. Oviposition preference and larval survival of Diprion pini on Scots pine clones in relation to foliage characteristics. Agric. For. Entomol. 2: 185-192.

Pautasso M., Holdenrieder O., and Stenlid J., 2005. Susceptibility to fungal pathogens of forests differing in tree diversity. In: SchererLorenzen M., Körner C. and Schulze E.-D. (Eds.), Forest diversity and function, temperate and boreal systems, ecological studies 176, pp. 263-289.

Peacock L. and Herrick S. 2000. Responses of the willow beetle Phratora vulgatissima to genetically and spatially diverse Salix spp. plantations. J. Appl. Ecol. 37: 821-831.

Peacock L., Hunter T., Turner H., and Brain P., 2001. Does host genotype diversity affect the distribution of insect and disease damage in willow cropping systems. J. Appl. Ecol. 38: 1070-1081.

Petercord R., 2005. Gefährden holzbesiedelnde Käfer die Rotbuche? Rheinische Bauernzeitung 49: 16-18.

Peterson D.L., Johnson M.C., Agee J.K., Jain T.B., McKenzie D., and Reinhard E.D., 2005. Forest structure and fire hazard in dry forests of the Western United States. PNW-GTR-628, U.S. Department of Agriculture, Forest Service, Pacific Northwest Research Station, Portland, Oregon, $30 \mathrm{p}$.

Petersson M., Nordlander G., and Örlander G., 2006. Why vegetation increases pine weevil damage: bridge or shelter? For. Ecol. Manage. 225: $368-377$.

Pietrzykowski E., McArthur C., Fitzgerald H., and Goodwin A.N., 2003. Influence of patch characteristics on browsing of tree seedlings by mammalian herbivores. J. Appl. Ecol. 40: 458-469.

Pinkard E.A., Baillie C., Patel V., and Mohammed C.L., 2006. Effects of fertilising with nitrogen and phosphorus on growth and crown condition of Eucalyptus globulus Labill. experiencing insect defoliation. For. Ecol. Manage. 231: 131-137.

Pinon J. and Cadic A., 2007. Les ormes résistants à la graphiose. Forêt Entreprise 175: 37-41.

Piri T. and Korhonen K., 2007. Spatial distribution and persistence of Heterobasidion parviporum genets on a Norway spruce site. For. Pathol. 37: 1-8.
Pitkanen A., Tormanen K., Kouki J., Jarvinen E., and Viiri H., 2005. Effects of green tree retention, prescribed burning and soil treatment on pine weevil (Hylobius abietis and Hylobius pinastri) damage to planted Scots pine seedlings. Agric. For. Entomol. 7: 319-331.

Poeppel S., 1994. Der Windwurf am 12. Februar 1894. Forst. Holz 49: 190.

Pollet J. and Omi P.N., 2002. Effect of thinning and prescribed burning on crown fire severity in ponderosa pine forests. Int. J. Wildl. Fire 11: $1-10$.

Pusenius J., Prittinen K., Roininen H., and Rousi, M., 2003. Effects of the availability of herbaceous food on vole attacks on birch seedlings. Ecoscience 10: 155-160.

Pyne S.J., Andrews P.L., and Laven R.D., 1996. Introduction to wildland fire, John Wiley, New York, 769 p.

Quine C.P., Coutts M.P., Gardiner B.A., and Pyatt D.G., 1995. Forests and wind: Management to minimise damage. Forestry Commission Bulletin 114: 1-27.

Ray D. and Nicoll B.C., 1998. The effect of soil water-table depth on root-plate development and stability of Sitka spruce. Forestry 71: 169-182.

Redfern D.B., 1984. Factors affecting spread of Heterobasidion annosum in plantations. In: Kyle G.A. (Ed.), Proceedings of the sixth IUFRO Conference on Root and Butt Rots of Forest Trees, Australia, August 1983, CSIRO, Melbourne, pp. 104-114.

Restif O. and Koella J.C., 2004. Concurrent evolution of resistance and tolerance to pathogens. Am. Nat. 164, E90-E102.

Rhoades C.C., Brosi S.L., Dattilo A.J., and Vincelli P., 2003. Effect of soil compaction and moisture on incidence of phytophthora root rot on American chestnut (Castanea dentata) seedlings. For. Ecol. Manage. 184: 47-54.

Robin C. and Desprez-Loustau M.L., 1998. Testing variability in pathogenicity of Phytophthora cinnamomi. Eur. J. Plant Pathol. 104: $465-475$.

Robinson R.M., 2003. Short-term impact of thinning and fertilizer application on Armillaria root disease in regrowth karri (Eucalyptus diversicolor F. Muell.) in Western Australia. For. Ecol. Manage. 176: 417-426.

Rochelle J.A., 1992. Deer and elk. In: Black H.C. (Ed.), Silvicultural approaches to animal damage, management in pacific northwest forests, Gen. Tech. Rep. PNW-GTR-287, U.S. Department of Agriculture, Forest Service, Pacific Northwestern Research Station, Portland, Oregon, pp. 333-350.

Rönnberg J., 2000. Logging operation damage to roots of clear-felled Picea abies and subsequent spore infection by Heterobasidion annosum. Silva Fenn. 34: 29-36.

Rönnberg J., Petrylaite E., Nilsson G., and Pratt J., 2006. Two studies to assess the risk to Pinus sylvestris from Heterobasidion spp. in southern Sweden. Scand. J. For. Res. 21: 405-413.

Root R.B., 1973. Organisation of a plant-arthropod association in simple and diverse habitats: the fauna of collards (Brassica oleracae). Ecol. Monogr. 43: 94-125.

Ross D.W., Berisford C.W., and Godbee J.F.Jr., 1990. Pine tip moth, Rhyacionia spp., response to herbaceous vegetation control in an intensively site-prepared loblolly pine plantation. For. Sci. 36: $1105-1118$.

Ross W.G., Kulhavy D.L., and Sun J.H., 2005. Effects of fertilization and herbicides on growth of young loblolly pine and infestations of Nantucket pine tip moth (Lepidoptera: Tortricidae). Insect Sci. 12: 367-374. 
Roth B.E. and Newton M., 1996. Role of lammas growth in recovery of Douglas-fir seedlings from deer browsing as influenced by weed control, fertilization, and seed source. Can. J. For. Res. 26: 936-944.

Rothermel R.C. and Philpot C.W., 1973. Predicting changes in chaparral flammability. J. For. 71: 640-643.

Rothermel R.C. and Philpot C.W., 1983. How to predict the spread and intensity of forest and range fires. GTR-INT-143, U.S. Department of Agriculture, Forest Service, Intermountain Forest and Range Experiment Station, $161 \mathrm{p}$.

Rousi M., Tahvanainen J., Henttonen H., and Uotila I., 1993. Effects of shading on resistance of winter-dormant birch (Betula pendula) to voles and hares. Ecology 74: 30-38.

Ryan K.C. and Reinhardt E.D., 1988. Predicting postfire mortality of seven western conifers. Can. J. For. Res. 18: 1291-1297.

Samalens J.-C., Rossi J.-P., Guyon D., Van Halder I., Menassieu P., Piou D., and Jactel, H., 2007. Adaptive roadside sampling for bark beetle damage assessment. For. Ecol. Manage. 253: 177-187.

Savill P., Evans J., Auclair D., and Falck J., 1997. Plantation silviculture in Europe, Oxford University Press, Oxford, 312 p.

Schelhaas M.J., Kramer K., Peltola H., van der Werf D.C., and Wijdeven S.M.J., 2007. Introducing tree interactions in wind damage simulation. Ecol. Model. 207: 197-209.

Schelhaas M.J., Nabuurs G.J., and Schuck A., 2003. Natural disturbances in the European forests in the 19th and 20th centuries. Glob. Change Biol. 9: 1620-1633.

Schreiner M., Aldinger E., and Bantle P., 1996. Standort und Sturmwurf 1990 - dargestellt am Östlichen Odenwald Nordöstlichen Schwarzwald. Mitt. Ver. Forst. Standortskd. Forstpflanzenztg. 38: $27-36$.

Schütz J.-P., Gotz M., Schmid W., and Mandallaz D., 2006. Vulnerability of spruce (Picea abies) and beech (Fagus sylvatica) forest stands to storms and consequences for silviculture. Eur. J. For. Res. 125: 291-302.

Selander J. and Immonen A., 1991. Effect of fertilization on the susceptibility of Scots pine seedlings to the large pine weevil Hylobius abietis. Folia Forestalia 771: 21.

Siemann E., Tilman D., Haarstad J., and Ritchie M., 1998. Experimental tests of the dependence of arthropod diversity on plant diversity. Am. Nat. 152: 738-750.

Sierpiński Z., 1972. Effect of stand density on fluctuations in population density of forest insect pests. Sylwan 2: 1-16.

Silen R.R., Olson D.L., and Weber J.C., 1993. Genetic variation in susceptibility to windthrow in young Douglas-fir. For. Ecol. Manage. 61: $17-28$.

Six D.L., Vander Meer M., DeLuca T.H., and Kolb P., 2002. Pine engraver (Ips pini) colonization of logging residues created using alternative slash management systems in Western Montana. West. J. Appl. For. 17: $96-100$.

Slodicák M., 1995. Thinning regime in stands of Norway spruce subjected to snow and wind damage. In: Coutts M.P. and Grace J. (Eds.), Wind and trees, Cambridge University Press, Cambridge, 436-447.

Smirnoff W.A. and Bernier B., 1973. Increased mortality of the Swaine jack-pine sawfly, and foliar nitrogen concentrations after urea fertilization. Can. J. For. Res. 3: 112-121.

Smit C., Vandenberghe C., den Ouden J., and Muller-Scharer H., 2007. Nurse plants, tree saplings and grazing pressure: changes in facilitation along a biotic environmental gradient. Oecologia 152:265-273.

Speight M.R. and Wainhouse D., 1989. Ecology and management of forest insects, Clarendon Press, Oxford, 374 p.
Stanosz G.R. and Patton R.F., 1987. Armillaria root rot in aspen stands after repeated short rotations. Can. J. For. Res. 17: 1001-1005.

Stiell W.M. and Berry A.B., 1986. Productivity of short-rotation aspen stands. For. Chron. 62: 10-15.

Stokes A., Nicoll B.C., Coutts M.P., and Fitter A.H., 1997. Responses of young Sitka spruce clones to mechanical perturbation and nutrition: effects on biomass allocation, root development, and resistance to bending. Can. J. For. Res. 27: 1049-1057.

Stone C., 2001. Reducing the impact of insect herbivory in eucalypt plantations through management of extrinsic influences on tree vigour. Austral Ecol. 26: 482-488.

Sun J., Kulhavy D.L., and Yan S., 1998. Prediction models of Nantucket pine tip moth, Rhyacionia frustrana (Comstock) (Lep., Tortricidae) infestation using soil and tree factors. J. Appl. Entomol. 122: 1-3.

Sun J.H., Kulhavy D.L., and Roques A., 2000. Effects of fertilizer and herbicide application on Nantucket pine tip moth infestation (Lep., Tortricidae). J. Appl. Entomol. 124: 191-195.

Syme P.D., 1975. The effects of flowers on the longevity and fecundity of two native parasites of the European pine shoot moth in Ontario. Environ. Entomol. 4: 337-346.

Tainter F.H. and Baker F.A., 1996. Principles of forest pathology, John Wiley \& Sons Ed. New York, 805 p.

Taylor S.P., Alfaro R.I., DeLong C., and Rankin L., 1996. The effects of overstory shading on white pine weevil damage to white spruce and its effects on spruce growth rates. Can. J. For. Res. 26: 306-312.

Thor M. and Stenlid J., 2005. Heterobasidion annosum infection of Picea abies following manual or mechanized stump treatment. Scand. J. For. Res. 20: 154-164.

Toda T., Tajima M., Nishimura K., and Takeuchi H., 1993. Resistance breeding to the pine wood nematode in Kyushu district. Progress of study after selection of the resistant clones. Bulletin of the Forest Tree Breeding Institute 11: 37-87.

Van Mantgem P.J., Stephenson N.L., Mutch L.S., Johnson V.G., Esperanza A.M., and Parsons D.J., 2003. Growth rate predicts mortality of Abies concolor in both burned and unburned stands Can. J. For. Res. 33: 1029-1038.

Van Nispen tot Sevenaer W.J.C.M., 1975. De gevolgen van de stormrampen voor de bosbouw in Nederland. Nederlands Bosbouw Tijdschrift 47: 41-52.

Van Soest J., 1954. Einheit in der Ertragskunde. Compte Rendus $11^{\mathrm{e}}$ Conférence IUFRO, Firenze, 1953, pp. 856-860.

Vaupel O., Dimitri L., and Vité J.P., 1981. Untersuchungen über den Einsatz von Lockstoffbekoederten Rohrfallen zur Bekämpfung des Buchdruckers (Ips typographus L.), sowie Moglichkeiten der Optimerung von Lockstofierfahren. Allg. Forst. Jagdztg. 152: 102-113.

Vehviläinen H. and Koricheva J., 2006. Moose and vole browsing patterns in experimentally assembled pure and mixed forest stands. Ecography 29: 497-506.

Vélez R., 1990. Mediterranean forest fires: A regional perspective. Unasylva 162: 3-9.

von Sydow F., 1997. Abundance of pine weevils (Hylobius abietis) and damage to conifer seedlings in relation to silvicultural practices. Scand. J. For. Res. 12: 157-167.

Wainhouse D., 2005. Ecological methods in forest pest management, Oxford University Press, Oxford, 288 p.

Wainhouse D., Ashburner R., Ward E., and Rose J., 1998. The effect of variation in light and nitrogen on growth and defence in young Sitka Spruce. Funct. Ecol. 12: 561-572. 
Wainhouse D., Staley J., Johnston J., and Boswell R., 2005. The effect of environmentally induced changes in the bark of young conifers on feeding behaviour and reproductive development of adult Hylobius abietis (Coleoptera : Curculionidae). Bull. Entomol. Res. 95: 151-159.

Wang G.G., 2002. Fire severity in relation to canopy composition within burned boreal mixedwood stands. For. Ecol. Manage. 163: 85-92.

Wargo P.M. and Harrington T.C., 1991. Host Stress and Susceptibility. In: Shaw C.G. and Kile G.A. (Eds.), Armillaria root disease, forest service, United States Department of Agriculture, Agriculture Handbook No. 691, Washington D.C., pp. 88-101.

Watt A.D., 1992. Insect pest population dynamics: effects of tree species diversity. In: Cannell M.G.R., Malcolm D.C., and Robertson P.A (Eds.), The ecology of mixed-species stands of trees, Blackwell Scientific Publications, Oxford, pp. 267-275.

Weatherspoon C.P. and Skinner C.N. 1995. An assessment of factors associated with damage to tree crowns from the 1987 wildfires in Northern California. For. Sci. 41: 430-451

Wellpott, A. 2008. The stability of continuous cover forests. Ph.D. thesis, University of Edinburgh, Edinburgh, 179 p.

Wermelinger B., 2004. Ecology and management of the spruce bark beetle Ips typographus - a review of recent research. For. Ecol. Manage. 202: 67-82.

Werner F. and Armann J., 1955. Stormfallningens dynamik - en studie. Svenska SkogsvForen. Tidskr. 53: 311-330.

White J.A. and Whitham T.G., 2000. Associational susceptibility of cottonwood to a box elder herbivore. Ecology 81: 1795-1803.

Wingfield M.J. and Swart W.J., 1994. Integrated management of forest tree diseases in South Africa. For. Ecol. Manage. 65: 11-16.
Winterhoff B., Schönfelder E., and Heiligmann-Brauer G., 1995. Sturmschäden des Frühjahrs 1990 in Hessen - Analyse nach Standorts- Bestandes- und Behandlungsmerkmalen. Forch. Ber. Hess. Landesanst. Forsteinrichtung, Waldforch. und Waldökologie, Hannover, Münden, 20.

Woodward S., Stenlid J., Karjalainen R., and Hüttermann A., 1998. Heterobasidion annosum. Biology, ecology, impact and control, CAB International, Cambridge, $589 \mathrm{p}$.

Worrell R., 1983. Damage by the spruce bark beetle in south Norway 1970-80: a survey, and factors affecting its occurrence. Medd. Nor. Skogforsoeksves. 38: 1-34.

Wolf, A., Moller, P.F., Bradshaw, R.H.W., and Bigler, J. 2004. Storm damage and long-term mortality in a semi-natural, temperate deciduous forest. For. Ecol. Manage. 188: 197-210.

Xu Y.-J., Rohrig E., and Folster H., 1997. Reaction of root systems of grand fir (Abies grandis Lindl.) and Norway spruce (Picea abies Karst.) to seasonal waterlogging. For. Ecol. Manage. 93: 9-19.

Zas R., Sampedro L., Prada E., Lombardero M.J., and Fernández-López J., 2006. Fertilization increases Hylobius abietis L. damage in Pinus pinaster Ait. seedlings. For. Ecol. Manage. 222: 137-144.

Zhang Q.H. and Schlyter F., 2004. Olfactory recognition and behavioural avoidance of angiosperm nonhost volatiles by conifer-inhabiting bark beetles. Agric. For. Entomol. 6: 1-19.

Zimmermann H., 1985. Zur Begründung von mischbeständen mit fichte und buche auf sturmwurfflächen im öffentlichen Wald Hessens. Allg. Forstz. 49: 1326-1330.

Zolciak A. and Sierota Z., 1997. Zabiegi hodowlane a zagrozenie drzewostanow przez patogeny korzeni. [Sylvicultural treatments and the threat to stands from root pathogens.] Prace Inst. Bad. Leś. B 33: $71-84$. 